This is a self-archived - parallel published version of this article in the publication archive of the University of Vaasa. It might differ from the original.

\title{
Does audit report information improve financial distress prediction over Altman's traditional Z-Score model?
}

Author(s): $\quad$ Muñoz-Izquierdo, Nora; Laitinen, Erkki K.; Camacho-Miñano, Maríadel-Mar; Pascual-Ezama, David

Title: Does audit report information improve financial distress prediction over Altman's traditional Z-Score model?

Year: $\quad 2019$

Version: $\quad$ final draft (post print, aam)

Copyright $\quad$ (C) 2019 John Wiley \& Sons

This is the peer reviewed version of the following article:

Muñoz-Izquierdo, N., Laitinen, E. K., Camacho-Miñano, M., \& Pascual-Ezama, D. (2019). Does audit report information improve financial distress prediction over Altman's traditional Z-Score model?. Journal of International Financial Management \& Accounting. https://doi.org/ 10.1111/jifm.12110

which has been published in final form at https://doi.org/10.1111/jifm.12110. This article may be used for non-commercial purposes in accordance with Wiley Terms and Conditions for Use of Self-Archived Versions. 


\section{Does audit report information improve financial distress prediction over}

\section{Altman's traditional Z-Score model?}

\section{Nora Muñoz-Izquierdo}

Accounting department, CUNEF (Colegio Universitario de Estudios Financieros), Leonardo Prieto Castro, 2, Ciudad Universitaria, 28040, Madrid, Spain

Email: nmunoz@cunef.edu (corresponding author)

\section{Erkki K. Laitinen}

Accounting department, University of Vaasa, P.O. Box 700, FI-65101 Vaasa, Finland.

Email: erkki.k.laitinen@uwasa.fi

\section{María-del-Mar Camacho-Miñano}

Accounting department, CUNEF (Colegio Universitario de Estudios Financieros), Leonardo Prieto Castro, 2, Ciudad Universitaria, 28040, Madrid, Spain

Email: marcamacho@,cunef.edu

\section{David Pascual-Ezama}

Financial Economics and Accounting II department (Accounting), Complutense University of Madrid, Facultad de Ciencias Económicas y Empresariales, Campus de Somosaguas, 28223, Pozuelo de Alarcón, Madrid, Spain

Email: david.pascual@,ccee.ucm.es

\footnotetext{
Acknowledgements: This paper was partly written when N. Muñoz-Izquierdo was a visiting scholar at the University of Vaasa (Finland). Comments and suggestions from participants of the 2016 EAA Doctoral Colloquium and 2016 ASEPUC conference are tremendously appreciated. Authors would also like to thank Oliver Lukason and Eduardo Ramos-Méndez for helpful feedback. Financial support of CUNEF and Complutense University of Madrid is gratefully acknowledged.
} 


\title{
Does audit report information improve financial distress prediction over
}

\section{Altman's traditional Z-Score model?}

\begin{abstract}
We analyze empirically the usefulness of combining accounting and auditing data in order to predict corporate financial distress. Concretely, we examine whether audit report information incrementally predicts distress over a traditional accounting model: the Altman's Z-Score model. Although the audit report seems to play a critical part in financial distress prediction because auditors should warn investors about any default risks, this is the first study that uses audit report disclosures for predicting purposes. From a dataset of 1,821 Spanish distressed private firms, we elaborate a sample of distressed and non-distressed firms and develop logit prediction models. Our results show that while the only accounting model registers a classification accuracy of 77 percent, combined models of accounting and auditing data exhibit considerably higher accuracy (about 87 percent). Specifically, findings indicate that the number of disclosures included in the report, as well as disclosures related to going concern, firms' assets and firms' recognition of revenues and expenses contribute the most to the prediction. Our evidence might have relevant implications for practice. For managers, as it highlights the importance of the audit report disclosures for anticipating a financial distress situation. Also, for regulators and auditors, due to the current international auditing environment, where regulation is changing worldwide in order to increase auditor's transparency through a more informative audit report.
\end{abstract}

Keywords: financial distress prediction, private companies, Altman's Z-Score, audit report, qualifications, emphasis of matter sections. 


\section{INTRODUCTION}

The topic of financial distress has been widely studied in the literature due to its negative consequences on both microeconomic and macroeconomic levels. Many stakeholders suffer from the effects of a situation where a firm is dealing with financial difficulties: from the shareholders of the business to its employees, customers, suppliers, financial institutions and the society, in general. Although there have been numerous studies on distress prediction in the past decades, an effort to improve the accuracy of prediction models continues to be needed (Balcaen and Ooghe, 2006; Du Jardin, 2015; Bauweraerts, 2016).

The literature on the modeling of corporate financial distress starts with the pioneer works of Beaver (1966) and Altman (1968), which are based on financial ratios. Since then, different approaches have been applied to improve accuracy, such as the selection of other financial ratios (see the reviews by Bellovary et al., 2007; Tascón-Fernández and Castaño-Gutiérrez, 2012), the application of more complex statistical and intelligent techniques ${ }^{1}$ like logistic analysis, hazard models or artificial intelligence (reviews by Balcaen and Ooghe, 2006; Kumar and Ravi, 2007) and the extension of traditional financial models with other variable sets like market variables (Merton, 1974; Hillegeist et al., 2004; Hernández-Tinoco and Wilson, 2013) and non-financial variables (Keasey and Watson, 1987; Lussier, 1995; Laitinen, 1999; Back, 2005; Cheng et al., 2007; Altman et al., 2010, 2015).

Studies that highlight the benefits of incorporating non-financial information in combination with financial ratios usually supplement financial factors by variables such as firm age, type of business and industry (Grunert et al., 2005), legal form, payment behavior, management structure (Laitinen, 1991), or group membership (Back, 2005). This trend of research also includes auditing data as non-financial factors. The most common examples are the type of auditor's opinion (Flagg et al., 1991; Altman et al., 2010, 2015; Wilson et al., 2013), the going concern opinion-generally issued when a firm's going concern status is in doubt- (Altman and McGough, 1974; Altman et al., 2010), number of qualified audits (Keasey and Watson, 1987; Piñeiro-Sánchez et al., 2013), auditor switching (Keasey and Watson, 1987; Altman et al., 2010), and auditor size and tenure (Piñeiro-Sánchez et al., 2013). However, these papers do not focus on the content of audit reports 
for anticipating financial distress (Muñoz-Izquierdo et al., 2017), and a related study of PiñeiroSánchez et al. (2013, pp.168) literally suggests "improving the codification of the qualifications to enhance the accuracy of the model". Thus, our investigation helps to fill this gap by empirically assessing the extent to which the combination of accounting and audit data included in the audit report predicts financial distress. The aim of this paper focuses on whether the classification accuracy of the Altman's Z'-Score model is improved by qualitative variables that represent the content of audit report disclosures.

Starting from a dataset of 1,821 financially distressed firms, a matched sample of 808 private manufacturing and non-manufacturing Spanish firms -404 distressed and 404 non-distressed companies- is manually created compiling financial, audit and legal information from two data sources: Bureau Van Dijk database (hereafter BVD)² and "Registro Público Concursal" (hereafter RPC $)^{3}$. For the definition of a distressed firm, the occurrence of insolvency filing is adopted (Lizarraga-Dallo, 1998; Piñeiro-Sánchez et al., 2013). This legal definition can be applied as the current Spanish law is based on a single court proceeding. This means that the legal procedure begins with the insolvency filing when a company is under financial distress, and the process finishes with either the reorganization or the liquidation of the firm ${ }^{4}$. The 404 distressed firms of the sample file for insolvency proceedings between 2004 and 2014. For the non-distressed firms' selection, the matching procedure is done by hand, based on year, size and industry, as in prior literature (Schwartz and Menon, 1985; Charitou et al., 2007; Knechel and Vanstraelen, 2007; Blay et al., 2011).

In this study, the Altman's Z' -Score is used as the benchmark model. First, this model is chosen because the sample consists of private companies from different industries and this is the version developed by Altman for private and public manufacturing and non-manufacturing firms (Altman, 1983). Second, and most importantly, the Z''-Score is selected due to its relevance, high recurrence and popularity in prior research. A recent study by Altman et al. (2017, pp. 133-134) argues that "even though the Z-Score model was developed more than 45 years ago and many alternative failure prediction models exist, the Z-Score model continues to be used worldwide as 
a main or supporting tool for bankruptcy or financial distress prediction and analysis both in research and in practice".

Then, this paper follows with the benchmark model supplemented by audit report information variables, examining their effect on the performance in terms of classification accuracy. Using the audit report codification of 20 dummy variables developed in Muñoz-Izquierdo et al. (2017), the content of the audit reports of the whole sample is extracted and manually labeled. In this codification, three of the variables represent the type of paragraph in which the disclosure is included (emphasis of matter section, scope limitation or $\mathrm{GAAP}^{5}$ violation), and the seventeen remaining typify the content of each disclosure. They include accounting issues as well as more general comments made by the auditors. The complete classification will be explained in the next sections. It is relevant to mention that such a broad investigation of audit data and, more specifically, an analysis of the audit report information has not been presented so far in corporate distress prediction studies (Laitinen and Laitinen, 2009a; Altman et al., 2010).

For all estimation models, logistic regression analysis is used following prior research (Balcaen and Ooghe, 2006), and predictions are provided for a horizon of one year. Thus, the ability of information in the period prior to filing is assessed to predict financial distress in the following year. Due to the manual process of analyzing every audit report in detail, the horizon is not expanded to more years. Also, prior studies demonstrate that typical accounting-based models are useful for prediction for one or two years prior to bankruptcy (Altman et al., 2015).

Results of this paper show that the combined use of financial and non-financial factors leads to a more accurate prediction of distress events than the single use of each of these factors. While the evidence indicates that the predictive power of the Z"-Score model is 77 percent, the classification accuracy improves 10 percent units (up to 87 percent) when audit report information is considered. Interestingly, consistent with prior literature that applies samples from different periods and countries - for example, Altman et al. (2010) using a sample of 5.8 million small and medium-sized enterprises from UK in the period 2000-2007 -, our results highlight the benefits of including the type of audit opinion in combination with financial ratios. Similarly, our evidence 
demonstrates the reliability and significant prediction power of the disclosure in the audit report related to going concern uncertainties. This result complements the stream of research that examines the usefulness of prediction models for evaluating going concern (Altman and McGough, 1974; Altman et al., 2010). Moreover, our findings also suggest that the number of disclosures ${ }^{6}$ included in the report, and disclosures related to firm assets' valuation and firm recognition of revenues and expenses are other audit variables that contribute to assess financial distress.

This paper updates the current literature in several ways. First, the Altman's Z"'-Score model is tested on a geographically different sample (Spain) covering a recent economic period (companies entering into a financial distress situation from 2004 to 2014). Country-specific models are less common estimations compared to generic bankruptcy prediction studies (Cultrera and Brédart, 2016). Specifically, due to the impact of the housing bubble in the Spanish economy, the number of corporate failures in Spain is increasing so more studies that explore potential predictors appear to be useful. Second, most of the distress literature focuses on public and large corporations whereas fewer studies are concerned about private firms (Peel and Peel, 1987), probably due to the easier access to their comprehensive financial data (Cultrera and Brédart, 2016). Our paper concentrates on private firms, contributing to this last body of research. Third, this work contributes to the line of research that uses both financial and non-financial factors for anticipating viability concerns. For the first time in financial distress prediction models for private companies in Spain, the contributions of both accounting variables and audit report information variables are examined. A unique sample is prepared manually and this study uses a recently published codification of narrative disclosures in the audit report to analyze the audit information of all firms in the data set (Muñoz-Izquierdo et al., 2017). The items of this codification are included as indicators of stress. By doing so, this paper eventually determines the significant prediction ability of the content of audit reports, and such extensive amount of auditing information has not been earlier applied in failure studies. Fourth, the use of audit report disclosures might serve to partially answer calls for research on what evidence auditors evaluate in the financial statements to 
determine the likelihood of firm failure, requested by Carson et al. (2013). Finally, it is believed that Spain constitutes an appropriate environment for distress assessments using audit data, as the audit regime is less severe than in other countries and non-litigious (Ruiz-Barbadillo et al., 2004; Arnedo-Ajona et al., 2008; Piñeiro-Sánchez et al., 2013). Then, the predictive power of auditing information might even increase if these models are tested in more severe contexts.

\section{PRIOR RESEARCH AND HYPOTHESES}

\section{Financial distress definition}

In prior literature, different definitions of financial distress have been used because most theoretical studies do not specify how to measure the decline of a firm's health (Argenti, 1976; Lukason and Hoffman, 2014). Some definitions are based on the ultimate legal consequence, either bankruptcy in the US (Charitou et al., 2007) and creditors' compulsory and/or voluntary liquidation in the UK (Peel et al., 1986; Liu, 2004). However, a company does not go bankrupt immediately, but goes through a failure process that varies considerably in length (Lukason and Hoffman, 2014). Wruck (1990) argues that there are several stages that a firm can go through before it is defined as dead: financial distress, insolvency, filing for bankruptcy, and administrative receivership in order to avoid the filing (Hernández-Tinoco and Wilson, 2013). Then, since the first stage, the company is failing to meet its financial obligations, although this does not inevitably lead to a bankruptcy filing.

We introduce a definition of financial distress because, when modeling financial risk, it is relevant to consider not only the event of bankruptcy as the primary outcome but also the time when a company fails to meet its financial obligations (Hernández-Tinoco and Wilson, 2013). For objectivity and accuracy purposes, we apply a narrow and legal definition of financial distress. The date of the beginning of the insolvency legal procedure is adopted as the indicator of financial distress (Larrinaga-Dallo, 1998; Piñeiro-Sánchez et al., 2013). With a sample of Spanish firms, the occurrence of the insolvency event can be used as the Spanish regulation (Bankruptcy Act $22 / 2003$ of July $9^{\text {th }}$ ) is based on a single court proceeding that starts when the company cannot 
pay its debts and finishes with the resolution of reorganization - if the firm is viable after legal proceedings - or the liquidation, otherwise.

Other studies use different indicators to define financial distress (Lukason and Hoffman, 2014). Wruck (1990) uses the time when the cash flow of a firm is not able to cover its current financial obligations with suppliers, employees and financial institutions. Barker and Duhaime (1997) define financial distress using different profitability measures to show the performance decline. For Andrade and Kaplan (1998), the indicator of financial distress is the first year that a firm's EBITDA is less than financial expenses. Whitaker (1999) takes into consideration the first year that a firm's cash flow is less than current maturities of long-term debt to assess financial distress. Thus, in prior literature accounting data is used in order to confirm financial distress i.e. whether the distressed firms in the sample have either a negative or a positive financial condition.

\section{Financial distress prediction using accounting data}

Previous research has tested the usefulness of accounting variables to assess financial distress. This common procedure is usually called the financial approach, or the usage of accounting-based variables to detect bankruptcy (Sun et al., 2014). Under this approach, there is a lack of consensus on variable selection (Balcaen and Ooghe, 2006). Nevertheless, the most popular prediction model is the Altman's Z-Score model, widely adopted in the literature (Balcaen and Ooghe, 2006; Du Jardin, 2015; Altman et al., 2017).

The original Z-Score model includes five ratios: working capital to total assets, retained earnings to total assets, earnings before interest and taxes to total assets, market value of equity to total liabilities, and sales to total assets. This original model is only applicable to publicly traded firms, as it utilizes the market value of equity. In the second version of the model, or the Z'-Score model, the market value of equity is replaced for the book value in the fourth ratio. However, the capital turnover ratio (sales to total assets) might derive in a potential industry effect if the sample includes other industries but manufacturing. The model continues its evolution to the last version, the Altman's Z"-Score, removing the capital turnover ratio and, by doing so, eliminating the industry effect. Thus, the Altman's Z"-Score model comprises four ratios, considered by prior failure research as a reliable representation of financial statement data (Scott, 1981; Laitinen, 
1991; Balcaen and Ooghe, 2006; Laitinen and Laitinen, 2009a): liquidity (working capital to total assets), cumulative profitability (retained earnings to total assets), profitability (earnings before interest and taxes to total assets) and leverage (book value of equity to total liabilities) ratios. As mentioned above, Altman et al. (2017) point out that the Z-Score model is applied worldwide as a main tool for analyzing bankruptcies both in research and practice. In the review of research by Bellovary et al. (2007) that traces the literature on bankruptcy prediction from the 1930's, it is suggested that multivariate discriminant analysis is one of the most promising methods for modeling distress, which was the analysis developed by Altman (1968). Moreover, they find that three of the top-ten ratios used in the literature of bankruptcy prediction belong to the Z"-Score model. These ratios are working capital by total assets, retained earnings by total assets and earnings before interest and taxes by total assets, and they are positioned in the ranking of most frequently used ratios in the third, fourth and fifth position, respectively. Similarly, Altman and Sabato (2007) choose to use the fourth ratio of the Z"-Score model due to its predictive power. In recent studies, the efficacy of the Z"-Score model has been tested. In the international work of Altman et al. (2017), they suggest that the model performs reasonably well for most countries. The classification performance, assessed by the AUC (Area under the Receiver Operating Characteristics Curve), is fair for Spain (an AUC of 0.734), which is approximately average accuracy. The current paper uses the last version of the model (the Z"-Score) because the sample contains Spanish, private, manufacturing and non-manufacturing companies (Altman, 1983), and the results validate the ones obtained for Spain in the international study. 


\section{Financial distress prediction using auditing data}

Many different approaches have been adopted to improve the accuracy of distress assessments, such as the application of different methodologies, the use of longer term processes in the prediction, and the selection of other types of variables like market data or non-financial variables (Altman et al., 2015). The majority of empirical papers focus on listed companies because the development of risk models for private companies is obviously limited by data availability, as market data is not available (Altman et al., 2010). Also, in the case of private companies, Balcaen and Ooghe (2006) point out the importance of supplementing accounting ratios by non-financial information, as annual financial statements might not be very reliable and stable over time. Similarly, Altman et al. (2015) suggest that the reliability of financial variables, especially for small and medium enterprises, is low because of instability and window dressing due to earnings management. Then, it seems that the financial statements of private firms might be combined with other data sources to complement their deficiencies and obtain a more accurate prediction.

Altman and Sabato (2007) propose that prediction accuracy may be improved by the use of qualitative information. The use of non-financial variables in prediction models has been well documented since Keasey and Watson (1987). Maltz et al. (2003) offer support for the inclusion of non-financial variables to assess default prediction. Testing 15 non-financial variables, Lussier (1995) indicates that the company's internal information related to its planning, advisoring, education and staff characteristics represent accurate predictors of failure for small companies. For credit risk estimation of Finnish companies, Laitinen (1999) uses a total of 35 variables, and 16 of them are non-financial variables related to characteristics of the firm: age, industry, payment behavior, management and legal structure, as well as inquiries about the firm in credit information bureau (Altman et al., 2015). Later, a reduced number of factors are applied in the study of Back (2005), such as the ones related to age, size, and group membership, and the results suggest that the number of payment delays was the variable with the highest predictive ability.

One category of non-financial variables is the one related to the auditing field. It is commonly accepted that the auditing profession guarantees the reliability of financial statements. Auditors should identify any potential signals of financial distress to warn investors and other users of the 
audit report of any possibility of failure (Mutchler, 1984; Lennox, 1999). As the audit report is the sole communication mechanism between the auditor and all interested parties, it should inform about any concerns or misstatements found in the annual accounts, so it can be considered as data to be included when assessing financial distress. Prior evidence concludes that audit data do signal useful incremental information about financial distress (Keasey and Watson, 1987; Hopwood et al., 1989; Flagg et al., 1991; Cheng et al., 2007; Altman et al., 2010; Piñeiro-Sánchez et al., 2013). The audit opinion has been the most studied audit variable in prior failure literature (Keasey and Watson, 1987; Hopwood et al., 1989; McKee, 2003; Kim et al., 2008; Laitinen and Laitinen, 2009b; Altman et al., 2010; Altman et al., 2015), and the most commonly studied audit qualification relates to the going concern (Altman and McGough, 1974; Flagg et al., 1991). This might be due to the direct impact of standards related to this decision, as well as its seriousness, as it implies that the company may not continue to exist in the foreseeable future (Mutchler, 1985; ISA, 570; SAS, 59). The seminal work of Altman and McGough (1974) was the first one to examine the usefulness of financial distress models for assessing going concern, that is, for evaluating if a firm was presumably not going to remain in business in the following period. Using a matched sample of 33 bankrupt and 33 non-bankrupt US public firms, their results suggested that a failure prediction model was more than 80 percent accurate when forecasting bankruptcy filings, in comparison with auditors' going concern assessment of 46 percent accuracy (Kuruppu et al., 2003). Later on, Altman et al. (2010) extend the study of the going concern opinion to other opinions, supporting that other severe qualifications, as well as the going concern, have high predictive ability and firms are more likely to fail since the auditor is questioning its viability. Our paper goes deeper into the content of the disclosures included by auditors in their reports, both in qualifications and in emphasis of matter paragraphs. Not only do we analyze the type of opinion but also the financial elements or other circumstances that drive the opinions, which are mentioned by auditors in those paragraphs. Therefore, we contribute to the existing literature on this matter by adding to the failure prediction other opinions apart from the going concern, as well as the content of the explanations of those opinions highlighted by auditors in emphasis of matter and qualification paragraphs. 
Other recent prediction papers argue for a combined approach testing both accounting and auditing data (Altman et al., 2010; Piñeiro-Sánchez et al., 2013). Keasey and Watson (1987) add variables specifically related to the auditing field to general non-financial variables, such as age, managerial structure and the date of submission of annual accounts, others. They test the importance of the unqualified/qualified opinion and the change of auditor, concluding that a combined model marginally make better predictions than models with financial variables or nonfinancial data only. A similar stream of research is followed by Flagg et al. (1991), who include the going concern auditor's opinion together with other financial and non-financial variables, finding the highest predictive power in a model that combines financial data with the going concern opinion and the information about a reduction of dividends. Later on, Cheng et al. (2007) show that the auditor switching is a significant attribute to predict failure. The predictive power of other auditor characteristics is studied by Piñeiro-Sánchez et al. (2013). They find that auditor rotation, qualified reports and non-compliance with deadlines regarding approval and filing of the financial statements present relevant differences between distressed and non-distressed firms.

Despite the focus on the audit opinion in failure prediction literature, as previously seen, studies that examine the effects of the content of audit reports in failure prediction are still scarce. Not only the final audit outcome should matter for predicting purposes, but also any comments contained in the audit report might represent relevant signals regarding the likelihood of future viability of the firm (Blay, 2005; Bauer, 2015). Thus, any disclosures mentioned in the report -in the form of emphasis of matter sections or qualifications-, represent concerns for the auditor and might be considered variables to be included in failure prediction studies. Piñeiro-Sánchez et al. (2013) encourage researchers to improve the codification of the qualifications in order to enhance the accuracy of predicting financial distress. Our work contributes to this stream of research because we assess financial distress using a combination of accounting data (summarized in the Altman's Z' -Score) and an extensive amount of qualitative data from the audit report, that is, the audit opinion, the number of disclosures included in emphasis of matter paragraphs and qualification paragraphs and the content of those disclosures. 
It seems that there is not a commonly used classification of the content of audit reports in the literature yet (Firth, 1978; Del Brío-González, 1998; Sánchez-Segura, 2000; Ruiz-Barbadillo et al., 2002; Herbohn and Ragunathan, 2008; Laitinen and Laitinen, 2009a; Muñoz-Izquierdo et al., 2017). Firth (1978) classifies qualifications into seven categories: general, going concern, asset values, subsidiary's audit, $\mathrm{SSAP}^{7}$, SSAP and concur, and continuing qualifications. Firth (1978) studies the impact of qualifications on investment decisions, finding that some information content of qualified audit reports on published accounts have a significant effect on those decisions, such as qualifications regarding going concern and asset valuation. Del Brío-González (1998) provides evidence on the effect of qualified audit reports on shares prices, suggesting that markets do not systematically react to qualifications in general, but a downward adjustment is shown when the auditor issues a "non-true and fair" qualification. A more simplified classification of qualifications is presented in this study, divided into going concern, assets and liabilities, result of the period and uncertainties and contingencies. Sánchez-Segura (2000) codifies the comments in terms of seriousness (from very severe to low severity). Her results suggest the presence of a solid relationship between the delay in signing the report and the existence of qualifications, and show that the more serious the qualification is the greater the delay. Additionally, Ruiz-Barbadillo et al. (2002) extend this classification, adding qualifications that are "evitable" and "inevitable". This study finds that the auditor's attitude has no influence on the quality of the accounting information. Herbohn and Ragunathan (2008) simplify the classification using types of opinion"except for (going concern)", "except for (other)", "subject to" and "inability to form an opinion" - and emphasis of matter section. According to Herbohn and Ragunathan (2008), there seem to be no evidence of earnings management leading to an audit opinion modification. However, they show that firms receiving inherent uncertainty modifications, or modifications other than going concern, have greater persistence of earnings accruals relative to other firms. A more recent work addresses the contingency effects of accruals on default assessment (Laitinen and Laitinen, 2009a). They use a codification of 10 audit outcomes related to the report (unmodified, not submitted or unclear), to remarks (on equity, on administration, and on balance sheet items valuation), to financial statements (with misstatements or not in accordance with the regulation) 
and to the liquidation proposal. They find that absolute accruals moderate audit report information, so the more accruals, the more important the information is. With a sample of Finnish firms, they obtain some remarks to be incremental explanatory variables of payment default prediction. In their study, the most relevant audit data are unmodified opinions, remarks on equity, and claims not in accordance with the companies' act. Another recent paper that classifies the content of audit reports is Muñoz-Izquierdo et al. (2017). They examine the effect of a 20-item codification on several features of the auditor and the audited firm, finding evidence of significant differences depending on auditor size, industry and financial condition of the audited firm, the quarter on which the court order is imposed and the legal procedure resolution.

Thus, it is clear that the classification of the content of audit reports is not consistent in the literature. The existing ones depend on the specific purpose of each research conducted, and none of the classifications are built with the purpose of predicting financial distress, combining the codification of the audit report information with financial data. With the aim of modeling distress, this paper makes use of Muñoz-Izquierdo et al.'s (2017) codification because it extends prior classifications and it is developed from a dataset of audit reports issued in the year before insolvency proceedings. As it seems that the majority of auditors' concerns will be issued at this time, this assures a thorough and complete codification, as well as it suits with the purpose of this work.

In addition, it is already verified that financial statements do not include all the information that is relevant to predict distress, and non-financial variables and, more precisely, audit variables, are likely to complement this deficiency. Then, it is expected that the incorporation of audit report disclosures into an accounting prediction model will provide incremental information regarding financial distress, so hypothesis one (H1) is proposed:

H1: The combined use of the Altman's Z'-Score model and the number of audit report disclosures leads to a more accurate prediction of distress events in the year prior to insolvency proceedings than the single use of the Altman's Z'-Score model.

To test this hypothesis, disclosures are measured using Muñoz-Izquierdo et al.'s (2017) codification (see section 3 for details). In $\mathrm{H} 1$, the incremental predictive value of a non-financial 
variable (the number of audit report disclosures included in every report) is solely examined. The content of disclosures is tested in hypothesis two (H2).

Similarly, for a reliable prediction model, it is essential to use not only a combination of accounting variables and number of audit report disclosures, but also the content of those disclosures (Firth, 1978; Del Brío-González, 1998; Sánchez-Segura, 2000; Herbohn and Ragunathan, 2008; Laitinen and Laitinen, 2009a). It is predicted that the accuracy to explain corporate financial distress will increment when combining financial data with the content of audit report disclosures. Therefore, the next hypothesis follows (H2):

H2: The combined use of the Altman's Z'-Score model and variables based on a classification of the content of the audit report disclosures leads to a more accurate prediction of distress events in the year prior to insolvency proceedings than the single use of the Altman's Z'-Score model. When building financial risk models, the incorporation of auditing data that captures the content of the audit report prior to insolvency legal proceedings is important in three main aspects. First, it adds information about the concerns that auditors express in the report in those critical moments when the viability of the company will be in danger. Second, such variables represent the quality of accounting data used in prediction distress, as the purpose of the external auditing is to ensure that the true and fair view of the company is shown in the financial statements. Third, auditing data contributes to accounting figures as annual financial information might not be very reliable for companies under financial difficulties. Overall, in the case of private companies, Balcaen and Ooghe (2006) point out the importance of supplementing accounting ratios by non-financial data. In summary, as stated before, there are few papers that have incorporated auditing data to default prediction and, more precisely, the information contained in the audit report, so this paper might be a contribution to this line of research. Additionally, most of the literature on distress prediction does not focus on private clients and a very limited amount of non-financial information is analyzed and used for modeling purposes, so this study is the first one to assess financial distress for private companies in Spain, combining both accounting variables and audit variables related with the content of audit reports. 


\section{METHODOLOGY}

\section{Sample}

The sample comprises 404 Spanish private firms under financial distress during the period 20042014 and a control sample of 404 financially non-distressed firms, matched by year, size and industry. In the present study, the data for the fiscal year prior to the distress situation is used and a legal definition of financial distress is followed, as in prior literature (Piñeiro-Sánchez et al., 2013). This study considers a company to be under financial risk in the moment when court proceedings begin. As explained in the previous section, there is a single court procedure in Spain that starts when the insolvency request is presented to the judge because the company cannot pay its debts, and ends with the reorganization or the liquidation of the firm (Camacho-Miñano et al., 2015).

The initial sample consisted of 1,821 firms that represent the universe of firms in the BVD database that had started insolvency proceedings as of January $31^{\text {st }}, 2015$. Thus, for a firm to be included in our sample, its proceedings must be ongoing as of the end of January 2015, regardless of the date on which the process began. Additionally, firms must be audited, registered in the RPC and with enough financial and audit data available in the BVD database to run the analyses. After filtering the dataset manually and excluding 1,417 firms (see Table 1), the final distressed sample consists of 404 firms $^{8}$. Following standard practice, financial institutions were removed from the sample, as they deal with different regulatory requirements, and their structural characteristics differ considerably from those of other firms (Charitou et al., 2007). The 404 distressed firms were matched based on size (total assets, to the extent possible), industry (4-digit $\mathrm{NACE}^{9}$ codes) and year (data from the same year). This matching procedure follows prior studies (Schwartz and Menon, 1985; Knechel and Vanstraelen, 2007; Carey et al., 2008; Blay et al., 2011). For the analyses, from the total dataset 75 percent of observations are randomly selected for estimation purposes (estimation sample), whereas the 25 percent remaining are used to validate the classification results (test sample). Sample selection criteria are summarized in Table 1. 
[Insert Table 1 here]

We report the characteristics of the final sample in Table 2. In Panel 1 we show the filing years of the 404 distressed firms. Whereas all filings occurred between 2004 and 2014, only 4 firms filed for bankruptcy before 2008; that is, our results are not significantly affected by the global financial crisis as most of the filings occurred after the crisis. We decide to leave all firms with ongoing proceedings as of the date of the data extraction (January $31^{\text {st }}, 2015$ ) because the period covered by the sample (2004-2014) is very appropriate for this study, as the Spanish Bankruptcy Act $22 / 2003$ of July 9 came into effect in 2004 , and changes to the new audit reporting regulatory changes started in $2015^{10}$. According to the NACE classification, we divide the sample into five industry categories in Panel 2 of Table 2. As per the matching process, there is obviously the same number of firms in each category. Therefore, there are no differences in the distribution of industries between distressed and non-distressed firms. Not surprisingly, the majority of firms belong to the construction and real-estate industry ( 35 percent), due to a substantial impact of the housing bubble in Spain after the global financial crisis. These firms are followed by manufacturing (27 percent), commercial (20 percent) and services companies (17 percent), which are also representative in the sample. In Panel 3, regarding age, the average for the total sample is 23 years, meaning that firms have experience on their markets. The median is 19 years for the distressed sample and 21 for the healthy firms. According to the Kolmogorov-Smirnov test, the sample does not follow a normal distribution for age. Then, the non-parametric Mann-Whitney U two-sample test is used to prove the null hypothesis that distressed and non-distressed firms are the same population with respect to age. In Panel 4, the size dimension shows an average of 84 million euros in total assets. Due to the matching selection criteria, there are no statistically significant differences in the distribution between distressed and non-distressed groups. As per the Kolmogorov-Smirnov test, the sample does not follow a normal distribution for size, so applying the Mann-Whitney U two-sample test it is verified that distressed and non-distressed firms are the same population with respect to size.

[Insert Table 2 here] 


\section{Logistic regression analysis and variables}

The logistic regression methodology is the statistical method adopted to test the hypotheses drawn. This methodology is commonly applied in distress studies, as it seems to fit well with the characteristics of the default prediction issue (Ohlson, 1980; Laitinen and Laitinen, 1998; Balcaen and Ooghe, 2006; Acosta-González and Fernández-Rodríguez, 2014).

For all the estimation models presented, we define DISTRESS as the dependent variable. DISTRESS is a dummy variable that equals 1 if a firm enters into insolvency proceedings and 0 otherwise. A binary variable is commonly used as the dependent variable in the default literature (Luoma and Laitinen, 1991; Laitinen, 1999). We define financially distressed firms as those who have started legal proceedings, because this is an objective moment that legally represents that a firm cannot pay its financial obligations. This leads to a legal, objective and narrow definition of financial distress previously used in the literature (Lizarraga-Dallo, 1998). In Spain, insolvency proceedings are single procedures that end with either the survival of firms or their liquidation.

The financial distress predictors or independent variables are summarized in Table 3. For their calculation, we extracted data from the BVD database. We report the independent accounting indicators in Panel 1. The accounting variables are taken from the Altman's Z"-Score model due to its current usage, popularity and efficacy according to prior literature (Altman, 1983; Balcaen and Ooghe, 2006; Bellovary et al., 2007; Altman et al., 2017). This model is composed of four financial ratios: working capital to total assets $(W C T A)$, retained earnings to total assets $(R E T A)$, earnings before interest and taxes to total assets (EBITTA), and book value of equity to total liabilities $(B V E T L)^{11}$. WCTA is a liquidity ratio that expresses the value of net current assets of a firm over total assets, and a decrease might represent a signal of viability problems, so firms with low liquidity are expected to be more financially distressed than firms with no liquidity issues. RETA displays the cumulative profitability as a proportion of total assets. As noted in prior studies, profitability is negatively linked to bankruptcy, so a negative correlation between this long term profitability measure and bankruptcy is expected. The ratio of earnings before interest and taxes to total assets $(E B I T T A)$ shows how productive a firm is in generating earnings before 
deducting interest and taxes, so a decline might indicate the existence of financial distress concerns. Thus, a lower profitability is hypothesized when firms are under financial distress. According to prior research, the return on assets ratio appears to be the most powerful predictor (Altman et al., 2017), as it continually outperforms other measures in assessing the risk of failure. Book value of equity to total liabilities (BVETL) captures leverage or capital structure. Shrinkages in this measure might be warning signs for financial difficulties, as it is expected that the distressed sample to be highly leveraged. BVETL measures if the value of equity gets lower than total debts with external parties.

This study also explores the bankruptcy predictive ability of external audit information, selecting the following audit explanatory variables: audit opinion (AUOPI), sum of disclosures in each audit report related to accounting variables $(A C C O M)$, and sum of disclosures about general or environmental circumstances (GRALCOM), such as regulatory issues. Their definitions are summarized in Panel 2. The audit opinion $(A U O P I)$ is a binary variable that takes the value of 0 if the opinion issued is unqualified, and 1 if it is qualified. On the one hand, an opinion is unqualified when the auditor determines that financial statements give a true and fair view in accordance with the reporting framework used for the preparation of the annual accounts. On the other hand, the auditor issues a qualified opinion if any significant modification or reservation is found in the financial statements. Thus, a qualified report is issued (i) when the financial statements are materially misstated in a particular account balance, class of transaction or disclosure that does not have pervasive effect on the financial statements, or (ii) when the auditor is unable to obtain evidence regarding balances, transactions or disclosures without pervasive effect on the financial statements. Additionally, auditors might also include emphasis of matter paragraphs when it is necessary to indicate significant uncertainties but disclosed appropriately in the notes to financial statements. These paragraphs do not qualify the auditors' opinion ${ }^{12}$. For the estimation models, an increase in the prediction power is expected once the audit opinion is considered and combined with accounting data, as prior evidence (Altman et al., 2010). Moreover, 
we also expect the likelihood of failure and the qualified opinions to move towards the same direction, so that a qualified opinion will lead to a financial distress situation.

The sum of disclosures related to accounting variables $(A C C O M)$ is a categorical variable that takes the value of 1 if the report mentions one comment regarding accounting issues, 2 if it contains two comments on this matter, and so on. The indicator is zero if there are no comments about accounting elements. The impact of the content of audit reports is very scarce in the literature. However, we expect that the number of accounting comments highlighted by the auditor provides incremental information regarding financial distress, as the report is the only mechanism available for the auditor to communicate any concerns about possibilities of failure. Disclosures included under this variable are represented in Table 4.

The sum of disclosures related to general or environmental circumstances, such as regulatory issues, is represented in the variable GRALCOM. This is a categorical variable that takes the value of 0 if there are no comments on this matter, 1 if one comment of this nature appears, 2 for two comments, and so on. We predict an increase in forecasting financial distress if the number of comments regarding the environmental context rises, as those will affect the company's financial condition and its viability. Disclosures summarized under this variable are contained in Table 4.

\section{[Insert Table 3 here]}

In order to test the predictive ability each audit report disclosure separately, we incorporate them to the estimations as independent indicators, using a recent classification in the literature (MuñozIzquierdo et al., 2017). This codification consists of 20 dummy variables, detailed in Table 4, that capture all possible audit report disclosures. In general, it is reasonable to assume that audit report disclosures will represent a signal of viability concerns, so those comments will provide incremental power for predicting bankruptcy.

The codification arranges the 20 items according to three categories: the type of paragraph or location in which disclosures are included, the accounting elements commented, or other circumstances that the auditor points out. There are 3 items in the first category (paragraph or 
location): emphasis of matter, modification due to a scope limitation, and modification due to a GAAP violation. The second category includes 12 items, regarding the accounting elements mentioned in the audit report. They are all related to assets (non-current and current), liabilities and contingencies, results, working capital information and data omission in the annual accounts. The last section or category has 5 items that underline the importance for auditors to mention external or environmental circumstances that may lead to a situation of financial distress in a firm. Those items contain information regarding regulatory issues, the market in which the firm operates, and signs that the company may not be able to pay its financial obligation in the current future. These are disclosures about going concern, about the company putting in practice a management plan to solve the financial situation or the firm starting legal proceedings. As per the above, it is reasonable to assume that a relevant number of audit report disclosures will represent increasing signals of viability concerns.

[Insert Table 4 here] 


\section{RESULTS}

\section{Summary statistics}

Summary statistics are reported for the accounting and auditing variables included as financial distress predictors in the logit models (Tables 5 to 7 ).

\section{[Insert Table 5 here]}

Descriptive statistics of the four ratios that compose the Altman's Z''-Score model are shown in Table 5. To control for extreme values, these variables are winsorized to the first and $99^{\text {th }}$ percentile. Consistent with prior studies, both mean and median for all ratios are lower for distressed than for non-distressed firms (Altman et al., 2017). Thus, as expected, financial predictors for firms facing insolvency proceedings in the subsequent year differ from financial predictors for healthy companies. At the p-level of 1 percent, all these differences between the two groups are statistically significant as per the non-parametric Mann-Whitney U two-sample test.

Firms dealing with viability concerns show lower level of liquidity, cumulative profitability, periodic profitability and lower equity to total debt. Whereas distressed firms have negative liquidity (mean WCTA is -9 percent), non-distressed companies show positive results ( 24 percent). Firms under financial distress have lower retained earnings as a percentage of total assets (mean RETA is -10 percent versus 30 percent) and the average return on assets (EBITTA) is also lower for distressed firms (-17 percent versus 2 percent) meaning that they regularly report very low earnings. Finally, it is interesting to mention that the value of equity over total liabilities presents an important gap from distressed to healthy firms (mean BVETL is 28 percent versus 173 percent). Overall, this univariate evidence is consistent with the expectation that firms with poorer economic performance are more likely to face financial distress.

The descriptive statistics for the audit explanatory variables are reported in Tables 6 and 7 . Regarding auditor size (Table 6 Panel 1), the most common auditor in the overall sample is a small-sized firm ( 58 percent of the 808 observations), followed by Big 4 auditors ( 24 percent), 
individual auditors (14 percent) and medium-sized firms (4 percent). Using the Chi-Square statistic, significant differences in the distribution of auditor size appear between distressed and non-distressed firms (p-value of 0.004). This indicates that the auditor's election by companies from the same industry and with the same value of assets differs depending on their financial condition. While big-sized auditors are more frequently hired by healthy firms, distressed companies prefer to be audited by smaller firms.

The univariate evidence on audit opinion (Table 6 Panel 2) shows the predictable differences between distressed and non-distressed firms, statistically significant at the p-level of 1 percent. In the distressed sample 55 percent are qualified opinions and there are 18 percent of qualified reports in the non-distressed group. This result indicates that many distressed companies in the sample did not receive any qualifications in the year prior to insolvency proceedings. This is known as Type II error or a false negative (Hopwood et al., 1989; Laitinen and Laitinen, 1998; Knechel and Vanstraelen, 2007; Carey et al., 2008). Type I error (or a false positive) is very rare in the sample. A Type I error appears when a firm receives a going concern modification but remain viable in the subsequent period. Although there are many qualified reports for nondistressed firms (18 percent of the non-distressed sample), only 14 are going concern qualifications (for more details see Table 7). Thus, this suggest that it is more common to see failed companies that did not receive a modified opinion prior to failure, or a Type II misclassification, which is more costly than a Type I error (Hernández-Tinoco and Wilson, 2013).

Turning to the content of audit reports (Panel 3 Table 6), the variable ACCOM represents the number of comments mentioned by auditors regarding issues with financial statements. As predicted, they are more frequent in distressed companies with very significant difference (pvalue of 0.000). Similarly, the sum of environmental disclosures in the audit report (GRALCOM), such as a general decline of sales in the market in which firms operate, a regulatory reform, or the beginning of court proceedings, shows a very significant difference between both groups (p-value of 0.000), appearing more regularly in distressed firms. Nevertheless, it is noticeable that some 
auditors did not disclose any comments (77 and 205, for accounting and environmental comments, respectively) for distressed companies.

\section{[Insert Table 6 here]}

In Table 7, the contingency table of the codification of audit report disclosures is reported. At the p-level of 1 percent, all the variables differ between distressed and non-distressed firms, meaning that differences on disclosures between groups are very significant. Not surprisingly, the frequency is higher for distressed firms, due to the fact that they represent emphasis of matter and modification paragraphs.

In particular, it is found that the most frequent type of paragraph is the emphasis of matter (EMPHA). 50 percent of distressed reports include this section, whereas it is present in 18 percent of cases where distress does not subsequently occur. As a matter paragraph does not modify the audit opinion, this result suggests that unmodified reports are more frequent in the study (see also Panel 2 of Table 6 , for the audit opinion).

In the sample, modified audit opinions are separated into modifications due to scope limitations $(S C O P E)$ and GAAP violation $(G A A P V)$. We find that about 36 percent of firms dealing with financial issues in the subsequent year have a scope limitation, and 25 percent contain a GAAP violation. These percentages decrease substantially in healthy firms. This result allows us to conclude that modified opinions appear in financially distressed firms more frequently than in healthy ones. This goes along with the idea that modified opinions provide signals of financial risk (Altman, 1984; Blay et al., 2011).

For distressed firms, the comments that appear the most regarding elements of the financial statements are associated with accumulated losses, short-term and long-term investments. Their high frequency relies on the idea that accumulated losses are only mentioned by auditors when the failure of the company is completely clear, as they do not normally provide unwarranted modified opinions (Geiger et al., 1998; Carey et al., 2008; Carcello and Neal, 2003). Audit report disclosures about financial investments are also more frequent in bankrupt firms, as profitability 
is mentioned by auditors when companies face significant warning issues. Added to this, in prediction models based on accounting-based ratios, the return on assets ratio is the most accurate bankruptcy predictor (Altman, 1968; Altman, 1983), so that this confirms the important value of comments on investments.

The highest number of remarks about general circumstances affecting a default company is 187 disclosures and they are related to comments about going concern $(G C)$ uncertainties. This evidence means that in 45 percent of cases, auditors issue a going concern opinion to a distressed firm. Predictably, going concern qualifications only appears 7 times in non-default companies. This result is consistent with the evidence found by Altman and McGough (1974). Even though this paper is from a different era of financial reporting and uses a smaller sample of US firms, they showed auditors' going concern assessment of 46 percent accuracy ${ }^{13}$. Interestingly, this means that nearly half of the auditors highlight important viability concerns when financial distress subsequently occurs. This evidence clearly anticipates the relevance of disclosures about viability uncertainties as predictors of financial distress. Thus, as mentioned above, the sample then provides evidence on audit reporting misclassifications. Despite the few cases of nondistressed companies that do receive a going concern modification (Type I misclassification), it is more common to see failed companies that did not receive a modified opinion prior to financial distress (Type II misclassification).

A remark associated with the firm entering into insolvency proceedings (INPROC) does not appear in healthy firms. Results show that 23 percent of risky firms contain this comment in the report, pointing out that those companies entered into voluntary legal proceedings. This finding is coherent with the usual practice of filing for bankruptcy protection in Spain, in order to avoid criminal responsibility in imminent bankruptcy situations (Pozuelo-Campillo et al., 2010; PiñeiroSánchez et al., 2013).

Finally, by this univariate analysis significant differences have been identified between distressed and non-distressed firms regarding audit report information. As the predictive ability of a detailed classification of the content of audit reports has not been tested so far in financial distress studies, 
this work incorporates the audit opinion $(A U O P I)$, the sum of disclosures (ACCOM and GRALCOM) and the 20-item codification of audit report disclosures to the logit estimation models.

[Insert Table 7 here]

\section{Pearson correlations}

In Table 8, we provide Pearson correlation coefficients among accounting and auditing indicators, and p-values represent the probability of observing these coefficients. In general, results confirm that correlations between the explanatory variables are significant but relatively low. The highest correlation is found between the profitability ratios (RETA and EBITTA).

In addition to the correlation matrix, we also present multicollinearity diagnostic tests of Tolerance Values (TOL) and Variance Inflation Factors (VIF). The multicollinearity problem appears when there is linear dependency among the independent variables. This may indicate that the coefficients estimated are not reliable. Although there is not a formal criterion to establish a VIF threshold, it has been generally accepted that VIF should be lower than 10 to demonstrate that collinearity is not significant (Neter et al., 1989; Hernández-Tinoco and Wilson, 2013). Our results show that there are no multicollinearity issues, as VIF are under $3^{14}$.

\section{[Insert Table 8 here]}

\section{Logistic regression models}

Moving to the multivariate analyses, logit models of financial distress probability are presented in Table 9, and their performance measures and classification accuracy are shown in Table 10. We develop four main models (Models 2 to 5) for predicting financial distress to study the contribution of auditing indicators to the predictive accuracy of a traditional model based on financial statement ratios, the Altman's Z''-Score model (Model 1). The models estimate the probability of financial distress in the year prior to observing this situation. They examine the predictive ability of each variable (accounting ratios and auditing information) and provide evidence about the variables that best discriminate between distressed and non-distressed firms. 
Model 1 represents the baseline model or the Altman's Z"-Score model tested in the sample. Models 2 to 5 are the combined models of accounting plus auditing information. In addition to the accounting ratios of the Altman's Z'-Score model, they all incorporate different audit variables. Model 2 includes the audit opinion $(A U O P I)$. Model 3 substitutes the opinion by the types of paragraphs included in the report: emphasis of matter (EMPHA), scope violation $(S C O P E)$ and GAAP violation paragraphs $(G A A P V)$. As per the codification of audit report disclosures, these variables represent items 1-3 (Muñoz-Izquierdo et al., 2017). Model 4 complements the accounting ratios with the two variables that represent the sum of all disclosures in each report related to accounting variables $(A C C O M)$ and to environmental circumstances (GRALCOM). Finally, the auditing information in Model 5 are the 17 variables remaining in the classification, the ones that represent the content of disclosures: 12 variables related to accounting elements mentioned and 5 variables that contain environmental circumstances also pointed out by auditors (Muñoz-Izquierdo et al., 2017).

The results of the Altman's Z'"-Score logit model appear in the second column of Table 9. Liquidity, profitability and leverage coefficients are negative, which conform to the predictions and to the findings of prior failure research (Altman et al., 2017). These results imply that financial distress likelihood decreases in liquidity, profitability, and leverage. However, the cumulative profitability ratio does not appear to be significant, which indicates that this ratio does not possess a high discriminating and predicting power. The insignificance of the cumulative profitability ratio $(R E T A)$ can be explained by the fact that the greater part of private firms in the sample are small so that the equity ratio (BVETL) already mainly reflects the accumulated profits (see also Table 8 for Pearson correlations between RETA and BVETL).

In the performance measures of Model 1 (second column of Table 10), the Nagelkerke R Square is 44 percent, which shows a moderately high strength of association. However, this measure (as well as the Cox \& Snell R Square) is only presented to make comparisons easier, but its interpretation should be treated with caution, as it does not have the same meaning for logit regressions as it has for ordinary least squares regressions (Hernández-Tinoco and Wilson, 2013). 
The classification accuracy of the model is measured by the AUC, which is the "Area under the Receiver Operating Characteristics Curve" and represents an appropriate and direct measure of the predictive accuracy of models estimated using logistic regressions. The classification accuracy of the model is very adequate because the AUC equals 0.861 . In the test sample, the model classifies correctly about 78 percent of the total sample, being 65 percent the correct classification of distressed and increasing to 92 percent for healthy firms. This higher percentage in the nondistressed group is also common in other studies (Altman et al., 2017). Thus, evidence indicates that 35 percent of distressed companies may share financial ratios results with non-distressed companies. Despite the sufficient classification ability of the model, the Hosmer \& Lemeshow test statistic is significant ( $\mathrm{p}$-value of 0.000 ), suggesting that this logit regression does not fit very well with the data.

The first model that mixes two data sources is Model 2 (third column of Table 9). In this model, all independent variables are negative and significant, with the exception of the cumulative profitability ratio (RETA), as it happened in Model 1. As noted by the model summary tests (third column of Table 10), this combination of financial ratios and audit opinion registers moderate strength of fit (a Nagelkerke $R$-square of 52 percent). The Hosmer \& Lemeshow test is not statistically significant ( $p$-value of 0.188 ), which indicates a very high goodness of fit with the data, improving the results from Model 1 . This model classifies correctly about 75 percent of firms in the test sample, with a classification performance of 0.878 (AUC), increasing the overall accuracy of Model 1. Interestingly, the classification accuracy of this model that includes the audit opinion is very similar to the one obtained by Altman and McGough (1974). Using completely different samples (808 Spanish private firms with 404 that entered bankruptcy proceedings during 2004-2014, and 66 US public firms with 33 bankrupt from 1970-1973), both studies build models that suggest a success in predicting bankruptcy filing of around 70 to 80 percent. Finally, although the AUC slightly increases compared to Model 1, the percentage of firms correctly classified does not improve. It might be due to high correlation between the audit opinion and the other variables, so this fact might be disruptive for the model accuracy (Balcaen and Ooghe, 2006). 
In Model 3, the opinion is substituted by the incremental contribution of the type of paragraph disclosed in the report (EMPHA, SCOPE and GAAPV). It is found that the coefficients of these three audit variables are statistically very significant at the p-level of 1 percent, and that the accounting ratios behave in the same way as in Models 1 and 2. Nagelkerke $R$-square in Model 3 increments to 60 percent but the model does not fit the data properly, as the Hosmer \& Lemeshow test is significant ( $p$-value of 0.048). The overall accuracy of the model increases in the test sample to 83 percent, and classification performance raises to an AUC of 0.906 . This result indicates that the estimation model improves by adding the information regarding the type of paragraph in which the report disclosures are located.

Model 4 substitutes the type of paragraphs by two variables that indicate the content of those paragraphs: the sum of audit report comments related to accounting and environmental circumstances (ACCOM and GRALCOM). At the p-level of 1 percent, audit coefficients are significant so that they are efficient predictors of the probability of financial distress. Similar to prior models, liquidity, profitability and leverage ratios have also high discriminating power. However, although the Nagelkerke $R$-square slightly increases to 63 percent compared to Model 3, this model still does not fit with the data, as the Hosmer \& Lemeshow test is significant (pvalue of 0.029 ). The overall accuracy of the model increments to 84 percent, and classification performance equals 0.919 . This evidence shows that with just two variables summarizing the content of the audit report is enough to obtain a precise estimation of financial distress. This is consistent with prior literature that suggests that higher model accuracy is not guaranteed with a greater number of factors, and that some models with very few number of factors are capable of surpassing the prediction of others with many more (Bellovary et al., 2007).

Model 5 includes the 17 items remaining of the classification of audit report disclosures (as the type of paragraph is included in Model 3), so it can be considered the most complete model estimated in this study. In terms of the Nagelkerke $R$-square, the strength of association increases to 68 percent with this model and, in this case, the goodness of fit is accurate because the Hosmer $\&$ Lemeshow test has a p-value of 0.151 . Moreover, the classification results, validated using the 
test sample, improve from previous models. The classification accuracy of the model significantly rises to 86 percent in the test sample (79 percent and 89 percent for the distressed and nondistressed groups, respectively), with an AUC of 0.929. Thus, 21 percent of problematic companies may have similar characteristics as healthy companies. As per the results just mentioned, this model can be considered as precise and conclusive.

As expected, financial ratios coefficients are statistically significant and negative, indicating the poor economic performance of bankrupt firms, with the exception of the cumulative profitability ratio that outlines a low predictive ability. These results are consistent with prior studies that determine the return on assets ratio and a leverage measure to be the best bankruptcy predictors in Spain (Lizarraga-Dallo, 1998).

Regarding audit data, some content of the audit report has a high ability on predicting financial distress. Results show significant coefficients for the audit report variables TNINA, LTINV, INV, STINV, REPER and GC which conform to the predictions. Moreover, these coefficients are statistically significant in the predicted direction because they have a positive sign. This evidence implies that financial distress likelihood increases when auditors issue comments on fixed assets, investments, inventories, revenues and expenses of the period and going concern uncertainties. In relation to the going concern qualification $(G C)$, our result goes in line with prior studies that also found the usefulness of the going concern opinion for assessing distress (Altman and McGough, 1974; Altman et al., 2010). In addition to this, other contents of the audit report found to be significant when predicting failure, such as comments regarding assets' valuations, depreciations and impairments (TNINA, LTINV, INV, STINV) or the recognition of revenues and expenses $(R E P E R)$ are novel findings that may contribute to explain the causes of financial distress.

When there is a need to compare the predictive ability of several logit models, prior literature recommends the use of the AUCs. Following Hernández-Tinoco and Wilson (2013), this paper carries out the comparisons using the non-parametric methodology introduced by Delong et al. (1988), which has not been previously applied in prediction studies that combine accounting and audit data. The comparison of ROC (Receiver Operating Characteristics) curves for the five 
models is presented in Figure 1, illustrating the differences in the predictive accuracy of all models through the interpretation of their respective AUCs. The closer each ROC curve is to the ideal point $(0,1)$, the more suitable its discriminating power. In other words, the closer the value of an AUC gets to 1, the more precise its discriminating ability.

With a Model 1 AUC of 0.861 , it is presumed that a standard set of liquidity, profitability and leverage ratios represents efficient predictors of financial distress probability. As Model 2 AUC moves to 0.878 , it is inferred that the contribution of the audit opinion is positive, though marginal. However, the substantial increase appears with the inclusion of audit variables more specifically related to the content of the report (Model 3 AUC is 0.906 , and Models 4 and 5 AUCs are 0.919 and 0.929 , respectively). Additionally, it is worth mentioning that, as per the nonparametric test of Delong et al. (1988), the five comparisons of AUCs show a p-value of 5 percent or smaller, which signifies that the AUCs differ from a statistical point of view and thus, the analysis is conclusive.

In summary, it can be concluded that the accuracy of models that combine financial and audit information is higher than a model of only accounting ratios. This important result suggests that audit information incrementally predicts bankruptcy over financial statements data. Therefore, the two hypotheses proposed in this study are supported, as the combination of both the number (H1) and the content of audit report disclosures (H2) exceed the predictive ability and accuracy of the only accounting model ${ }^{15}$.

[Insert Tables 9 and 10, and Figure 1 here] 


\section{CONCLUSION}

Modeling the prediction of financial distress has been a recurrent research topic in the academic literature for decades because, if a firm collapses, the consequences for both the company and all related parties can be devastating (Bauweraerts, 2016; Cultrera and Brédart, 2016). Given the fact that firm failures are increasing worldwide in the past years, mainly due to the impact of the global financial crisis in the many economies, there is still scope for further investigation regarding the improvement of modeling prediction accuracy (Reznakova and Karas, 2014) and the need to develop a global bankruptcy theory (Du Jardin, 2017).

The aim of this paper is to examine the extent to which audit report information incrementally predicts financial distress over accounting ratios using a traditional accounting-based model: the Altman's Z'-Score model. Using a sample of 404 distressed and 404 non-distressed Spanish private firms, we build 5 logistic regression models of only accounting data and a combination of accounting and auditing data. They all possess a high discriminating and predicting power. However, it is verified that the classification accuracy of the estimated logit models significantly increases with models that combine accounting and audit data, compared to a traditional financial ratios model. Concretely, together with liquidity, profitability and leverage ratios, the number of disclosures included in the report, and remarks on going concern, firms' assets and firms' results are the best corporate distress predictors.

The present study represents a contribution to the existing literature for several reasons. Firstly, it determines the predictive ability of the Altman's Z'-Score in a current sample of Spanish private firms, providing country-specific results, which are less frequent than generic bankruptcy prediction models (Cultrera and Brédart, 2016). Secondly, it extends earlier research on distress prediction by using combined models of financial and non-financial indicators, as suggested in prior literature (Balcaen and Ooghe, 2006). More specifically, in this research it is possible to explore the value added by audit report information to distress prediction (Altman et al., 2010, 2017) not previously done before. Actually, there is a call from the literature that precisely asks for asking for "improving the codification of the qualifications to enhance the accuracy of the 
model" (Piñeiro-Sánchez et al. (2013, pp.168). Thirdly, it is believed that Spain constitutes an ideal environment to test the models because the audit regime is more flexible than in the AngloSaxon countries (Arnedo-Ajona et al., 2008; Ruiz-Barbadillo et al., 2004). If the audit information is found to be an efficient predictor under a flexible and non-litigious regime, the significance of these results might strengthen in other countries with more severe regimes. Finally, the thorough analysis of the audit report disclosures presented in this paper responds to some needs from the literature asking for studies on what auditors currently evaluate in terms of financial statement items and client contrary and mitigating factors in making their substantial doubt and going concern assessments (Carson et al., 2013). The disclosures mentioned by auditors under financial distress situations might shed some light on this issue. Finally, our results might have relevant implications for practice. For managers, this study highlights the importance of the audit report, a quick and accessible tool to look at when trying to anticipate a financial distress situation. With the existence of several audit report disclosures or just a few of them regarding issues with assets or results, this might represent uncertainties to consider carefully in decision-making processes. Also, for regulators and auditors, due to the current international auditing environment, where regulation is changing worldwide in order to increase auditor's transparency through a more informative audit report.

This study has some limitations that must be acknowledged. First, financial distress prediction is addressed using a sample of Spanish private firms. These firms may have special characteristics due to the institutional and legal context that might impair the generalization of the results. In further studies, these models can be replicated in other contexts for comparison purposes. Second, static bankruptcy predictors of the year prior to bankruptcy filing are used. In further works, variation variables that consider year-on-year differences should be developed. Finally, further research could extend the sample to other territories with different regulatory regimes for comparison purposes. 
Table 1. Sample selection criteria

\begin{tabular}{lc}
\hline Initial sample & 1,821 \\
(-) Companies not registered as bankrupt in the RPC & $(280)$ \\
(-) Companies with missing financial data from the year prior to insolvency & $(774)$ \\
(-) Companies with missing audit data from the year prior to insolvency & $\frac{(363)}{404}$ \\
Sample of distressed firms & $\frac{404}{808}$ \\
\hline Matched sample of non-distressed firms & Final sample
\end{tabular}

The table reports the sample selection criteria. RPC ("Registro Público Concursal") is the official insolvency legal proceedings' source in Spain. The initial sample was extracted from BVD database as of January $31^{\text {st }}, 2015$ using the status "suspension of payment proceedings", "bankruptcy", and "insolvency proceedings", and excluding firms with no information under "auditor's opinion" to ensure that all companies were audited. After filtering the dataset, the final sample comprises all firms registered in RPC with enough financial and audit data of the year prior to insolvency proceedings, matched by year, size and industry with 404 non-distressed firms. 
Table 2. Descriptive statistics of the sample

Panel 1. Frequencies of years in the distressed sample (in percent)

\begin{tabular}{cc}
\hline Years & Distressed \\
\hline 2004 & $1(0)$ \\
\hline 2005 & $1(0)$ \\
\hline 2006 & $1(0)$ \\
\hline 2007 & $1(0)$ \\
\hline 2008 & $23(6)$ \\
\hline 2009 & $24(6)$ \\
\hline 2010 & $21(5)$ \\
\hline 2011 & $29(8)$ \\
\hline 2012 & $65(16)$ \\
\hline 2013 & $146(36)$ \\
\hline 2014 & $92(23)$ \\
\hline Total & $404(100)$ \\
\hline
\end{tabular}

Panel 2. Frequencies of industries (in percent)

\begin{tabular}{lccc}
\hline & Distressed & Non-distressed & Total \\
\hline Construction and real-estate & $141(35)$ & $141(35)$ & $282(35)$ \\
Manufacturing & $110(27)$ & $110(27)$ & $220(27)$ \\
Commercial & $79(20)$ & $79(20)$ & $158(20)$ \\
Services & $70(17)$ & $70(17)$ & $140(17)$ \\
Primary & $4(1)$ & $4(1)$ & $8(1)$ \\
Total & $404(100)$ & $404(100)$ & $808(100)$ \\
\hline
\end{tabular}

Panel 3. Age of firms (in years)

$\begin{array}{lccc}\text { Median } & 19 & 21 & 20 \\ \text { Min. } & 4 & 3 & 3 \\ \text { Max. } & 79 & 81 & 81 \\ \text { Mean } & 22 & 23 & 23 \\ \text { Std. Dev. } & 13 & 14 & 13 \\ \text { Mann-Whitney U statistic } & & 159,870 & \\ \text { p-value } & & .285 & \end{array}$

Panel 4. Size of firms

\begin{tabular}{lccc} 
Median & 15,318 & 15,261 & 15,261 \\
Min. & 453 & 416 & 416 \\
Max. & $2,873,883$ & $3,736,210$ & $3,736,210$ \\
Mean & 84,352 & 84,431 & 84,392 \\
Std. Dev. & 276,969 & 293,514 & 285,185 \\
Mann-Whitney U statistic & & 163,153 & \\
p-value & & .936 & \\
\hline
\end{tabular}

In this table, the filing years of the distressed sample are provided (Panel 1). The five categories classification of industries is created based on NACE codes (Panel 2). The age is expressed in years (Panel 3 ) and, for the size of the firms, the value of total assets in thousands of euros is used (Panel 4). 
Table 3. Independent variables: accounting variables, audit opinion, and number of disclosures

\begin{tabular}{|c|c|c|}
\hline \multicolumn{3}{|c|}{ Panel 1. Accounting variables } \\
\hline Variable & Formula & Definition \\
\hline$W C T A$ & WCTA $=\frac{\text { Working capital }}{\text { Total assets }}$ & $\begin{array}{l}\text { Working capital or net current assets } \\
\text { (current assets minus current liabilities) to } \\
\text { total assets. }\end{array}$ \\
\hline RETA & RETA $=\frac{\text { Retained earnings }}{\text { Total assets }}$ & Retained earnings to total assets. \\
\hline EBITTA & $E B I T T A=\frac{E B I T}{T A}$ & $\begin{array}{l}\text { Earnings before interest and taxes to total } \\
\text { assets. }\end{array}$ \\
\hline BVETL & $B V E T L=\frac{B V E}{T L}$ & Book value of equity to total liabilities. \\
\hline \multicolumn{3}{|c|}{ Panel 2. Audit opinion and number of disclosures } \\
\hline Variable & Explanation & Definition \\
\hline AUOPI & Audit opinion & $\begin{array}{l}\text { Dummy variable that equals } 1 \text { if a qualified } \\
\text { opinion is issued in the year prior to } \\
\text { insolvency proceedings; } 0 \text { if the opinion is } \\
\text { unqualified. }\end{array}$ \\
\hline$A C C O M$ & $\begin{array}{l}\text { Sum of accounting disclosures in } \\
\text { the audit report }\end{array}$ & $\begin{array}{l}\text { Categorical variable that equals } 1 \text { if the } \\
\text { audit report has } 1 \text { comment regarding } \\
\text { accounting issues, } 2 \text { if it has two comments } \\
\text { on this matter, and so on; } 0 \text { if there are no } \\
\text { comments. }\end{array}$ \\
\hline GRALCOM & $\begin{array}{l}\text { Sum of general disclosures in the } \\
\text { audit report }\end{array}$ & $\begin{array}{l}\text { Categorical variable that equals } 1 \text { if the } \\
\text { audit report has } 1 \text { comment of this nature, } \\
2 \text { if it has two comments, and so on; } 0 \text { if } \\
\text { there are no comments. }\end{array}$ \\
\hline
\end{tabular}

This table reports independent accounting and auditing variables of the logit models, with the exception of the codification of audit report disclosures (see Table 4). WCTA states for working capital to total assets; RETA: retained earnings to total assets; EBITTA: earnings before interest and taxes to total assets; BVETL: book value of equity to total liabilities; $A U O P I$ : Audit opinion; $A C C O M$ : sum of accounting disclosures in the audit report; GRALCOM: sum of general or environmental disclosures in the audit report. 


\section{Table 4. Codification of audit report disclosures}

\begin{tabular}{|c|c|c|c|}
\hline \multicolumn{2}{|c|}{ Codification } & Variable & Description \\
\hline \multirow[t]{4}{*}{ A. } & \multicolumn{3}{|l|}{ Type of paragraph used for disclosure } \\
\hline & Emphasis of matter & EMPHA & $\begin{array}{l}\text { Dummy variable that equals } 1 \text { if an emphasis of matter section is issued in the year prior to insolvency } \\
\text { proceedings; } 0 \text { otherwise. }\end{array}$ \\
\hline & Scope limitation & SCOPE & Dummy variable that equals 1 if a scope limitation is issued; 0 otherwise. \\
\hline & 3. GAAP violation & $G A A P V$ & Dummy variable that equals 1 if a GAAP violation is issued; 0 otherwise. \\
\hline \multirow[t]{13}{*}{ B. } & \multicolumn{3}{|c|}{ Specific accounting elements affected $(A C C O M)$} \\
\hline & $\begin{array}{l}\text { NCA: tangibles and } \\
\text { intangibles }\end{array}$ & TNINA & Dummy variable that equals 1 if a remark on tangible or intangible assets is issued; 0 otherwise. \\
\hline & NCA: LTFI & LTINV & Dummy variable that equals 1 if a remark on LTFI is issued; 0 otherwise. \\
\hline & NCA: deferred tax assets & DTA & Dummy variable that equals 1 if a remark on DTA is issued; 0 otherwise. \\
\hline & CA: inventories & $I N V$ & Dummy variable that equals 1 if a remark on inventories is issued; 0 otherwise. \\
\hline & CA: STFI and cash & STINV & Dummy variable that equals 1 if remark on inventories is STFI; 0 otherwise. \\
\hline & Liabilities: debts & $\angle I A B$ & Dummy variable that equals 1 if a remark on liabilities is issued; 0 otherwise. \\
\hline & Contingencies & CONTIN & Dummy variable that equals 1 if a remark on inventories is issued; 0 otherwise \\
\hline & Result of the period & REPER & Dummy variable that equals 1 if a remark on the result of the period is issued; 0 otherwise. \\
\hline & Accumulated losses & ACLOSS & Dummy variable that equals 1 if a remark on accumulated losses is issued; 0 otherwise. \\
\hline & Information omitted & INFOM & Dummy variable that equals 1 if a remark on information omission is issued; 0 otherwise. \\
\hline & Negative working capital & $N E G W C$ & Dummy variable that equals 1 if a remark on negative working capital is issued; 0 otherwise. \\
\hline & 15. Subsequent events & SUBSEQ & Dummy variable that equals 1 if a remark on subsequent events is issued; 0 otherwise. \\
\hline \multirow[t]{6}{*}{ C. } & \multicolumn{3}{|c|}{ Other circumstances disclosed (GRALCOM) } \\
\hline & 16. Regulatory effects & REGUL & Dummy variable that equals 1 if a remark on regulation is issued; 0 otherwise. \\
\hline & $\begin{array}{l}\text { External economic } \\
\text { environment }\end{array}$ & ENVIR & Dummy variable that equals 1 if a remark on environmental or external factors is issued; 0 otherwise. \\
\hline & Management plan & MGMTP & Dummy variable that equals 1 if a remark on management plans is issued; 0 otherwise. \\
\hline & $\mathrm{GC}$ & $G C$ & Dummy variable that equals 1 if a remark on going concern is issued; 0 otherwise. \\
\hline & Insolvency proceedings & INPROC & Dummy variable that equals 1 if a remark on insolvency proceedings is issued; 0 otherwise. \\
\hline
\end{tabular}

The table reports the codification of audit report disclosures, segregated into three sections: location or paragraph (A), accounting elements (B) and general circumstances (C). The table shows the section (first column), the item/variable number, name and abbreviated name (second, third and fourth column, respectively), and the variable definition (fifth column). GAAP states for "Generally Accepted Accounting Principles"; NCA: "non-current assets"; LTFI: "long-term financial investments"; DTA: "Deferred tax assets"; $C A$ : "current assets"; STFI: "short term financial investments" and $G C$ : "going concern". 
Table 5. Summary statistics of Model 1 (Altman's Z'-Score model)

\begin{tabular}{|c|c|c|c|c|c|c|c|c|c|c|c|c|c|c|c|c|}
\hline \multirow{2}{*}{ Variables } & \multicolumn{7}{|c|}{$\begin{array}{c}\text { Distressed } \\
(\mathrm{n}=404)\end{array}$} & \multicolumn{7}{|c|}{$\begin{array}{l}\text { Non-distressed } \\
\quad(\mathrm{n}=404)\end{array}$} & \multicolumn{2}{|c|}{ Comparison } \\
\hline & Mean & Std. Dev. & Min. & Max. & $\mathrm{P} 25$ & P75 & Med. & Mean & Std. Dev. & Min. & Max. & $\mathrm{P} 25$ & P75 & Med. & $\begin{array}{c}\text { Mann- Whitney } \\
U \text { test }\end{array}$ & $p$-value \\
\hline$W C T A$ & -.090 & .401 & -1.556 & .883 & -.250 & .128 & -.038 & .239 & .307 & -1.556 & .883 & .036 & .426 & .199 & $38,901.5$ & .000 \\
\hline RETA & -.104 & .481 & -1.965 & .853 & -.207 & .137 & .003 & .300 & .345 & -1.898 & .889 & .137 & .528 & .294 & $31,292.0$ & .000 \\
\hline EBITTA & -.169 & .329 & -1.712 & .318 & -.184 & -.005 & -.065 & .026 & .104 & -.641 & .318 & -.005 & .064 & .030 & $28,393.5$ & .000 \\
\hline BVETL & .278 & 1.098 & -.633 & 15.493 & -.084 & .348 & .093 & 1.728 & 3.015 & -.633 & 15.493 & .302 & 1.669 & .649 & $31,772.0$ & .000 \\
\hline
\end{tabular}

This table presents summary statistics for Altman's Z"'-Score model, which includes only accounting variables. It covers mean, standard deviation, minimum and maximum values, percentiles $25^{\text {th }}$ and $75^{\text {th }}$, and median for the four ratios used in the logistic regression: working capital to total assets (WCTA), retained earnings to total assets $(R E T A)$, earnings before interest and taxes to total assets $(E B I T T A)$ and book value of equity to total liabilities $(B V E T L)$. All ratios are winsorized to the first and $99^{\text {th }}$ percentile to avoid extreme values. Due to winsorizing, some maximum and minimum values are identical for distressed and non-distressed firms. The nonparametric Mann-Whitney U two-sample test is applied to test the null hypothesis that distressed and non-distressed firms are the same population with respect to accounting variables and two-tailed significance is reported. The number of observations in the total sample is 808 (404 distressed and 404 non-distressed). 
Table 6. Frequency (and percentage) of audit variables

\begin{tabular}{|c|c|c|c|}
\hline \multicolumn{4}{|l|}{ Panel 1. Auditor size } \\
\hline Categories & Distressed (404) & Non-distressed (404) & Total (808) \\
\hline Big 4 & $76(39)$ & $119(61)$ & $195(100)$ \\
\hline Medium & $22(61)$ & $14(39)$ & $36(100)$ \\
\hline Small & $248(53)$ & $219(47)$ & $467(100)$ \\
\hline Individuals & $58(53)$ & $52(47)$ & $110(100)$ \\
\hline Chi-Square statistic & & 13.388 & \\
\hline Df & & 3 & \\
\hline p-value & & .004 & \\
\hline \multicolumn{4}{|c|}{ Panel 2. Audit opinion $(A U O P I)$} \\
\hline Categories & Distressed (404) & Non-distressed (404) & Total $(808)$ \\
\hline Unqualified & $183(36)$ & $330(64)$ & $513(100)$ \\
\hline Qualified & $221(75)$ & $74(25)$ & $295(100)$ \\
\hline Chi-Square statistic & & 115.374 & \\
\hline Df & & 1 & \\
\hline p-value & & .000 & \\
\hline \multicolumn{4}{|c|}{ Panel 3. Specific accounting elements affected $(A C C O M)$} \\
\hline Categories & Distressed (404) & Non-distressed (404) & Total (808) \\
\hline No comments & $77(22)$ & $271(78)$ & $348(100)$ \\
\hline 1 comment & $159(60)$ & $106(40)$ & $265(100)$ \\
\hline 2 comments & $125(83)$ & $26(17)$ & $151(100)$ \\
\hline 3 comments & $39(97)$ & $1(3)$ & $40(100)$ \\
\hline 4 comments & $2(100)$ & $0(0)$ & $2(100)$ \\
\hline 5 comments & $2(100)$ & $0(0)$ & $2(100)$ \\
\hline Chi-Square statistic & & 223.757 & \\
\hline Df & & 5 & \\
\hline p-value & & .000 & \\
\hline \multicolumn{4}{|c|}{ Panel 4. Other circumstances disclosed (GRALCOM) } \\
\hline Categories & Distressed (404) & Non-distressed (404) & Total (808) \\
\hline No comments & $205(35)$ & $378(65)$ & $583(100)$ \\
\hline 1 comment & $71(80)$ & $18(20)$ & $89(100)$ \\
\hline 2 comments & $70(95)$ & $4(5)$ & $74(100)$ \\
\hline 3 comments & $55(93)$ & $4(7)$ & $59(100)$ \\
\hline 4 comments & $3(100)$ & $0(0)$ & $3(100)$ \\
\hline Chi-Square statistic & & 188.848 & \\
\hline Df & & 4 & \\
\hline p-value & & .000 & \\
\hline
\end{tabular}

This table presents the summary statistics of the auditing variables (audit report disclosures' statistics detailed in Table 7). Data is divided by distressed, non-distressed and overall samples. Absolute figures indicate frequency of each variable and percentages over total sample are reported in parenthesis. Samples are classified by auditor size and type of opinion (Panels 1 and 2). Panels 3 and 4 inform about the number of accounting and environmental disclosures respectively. Chi-Square statistic shows whether differences exist in the distribution of each audit variable between distressed and non-distressed firms. Degrees of freedom (Df) and significance are also reported below the statistic. 
Table 7. Frequency (and percent) of audit report disclosures

\begin{tabular}{|c|c|c|c|c|c|c|}
\hline \multirow[b]{2}{*}{ Variables } & \multirow[b]{2}{*}{$\begin{array}{l}\text { Distressed } \\
(\mathrm{n}=404)\end{array}$} & \multirow[b]{2}{*}{$\begin{array}{c}\text { Non- } \\
\text { distressed } \\
(\mathrm{n}=404)\end{array}$} & \multirow[b]{2}{*}{$\begin{array}{c}\text { Total } \\
(\mathrm{n}=808)\end{array}$} & \multicolumn{3}{|c|}{ Comparison } \\
\hline & & & & $\begin{array}{l}\text { Chi- } \\
\text { Square } \\
\text { statistic }\end{array}$ & Df & $\begin{array}{c}p- \\
\text { value }\end{array}$ \\
\hline \multicolumn{7}{|c|}{ A. Type of paragraph used for disclosure } \\
\hline 1. EMPHA & $202(74)$ & $73(26)$ & $275(100)$ & 91.734 & 1 & .000 \\
\hline 2. $S C O P E$ & $144(86)$ & $24(14)$ & $168(100)$ & 108.214 & 1 & .000 \\
\hline 3. $G A A P V$ & $102(67)$ & $51(33)$ & $153(100)$ & 20.971 & 1 & .000 \\
\hline \multicolumn{7}{|c|}{ B. Specific accounting elements affected $(A C C O M)$} \\
\hline 4. TNINA & $31(76)$ & $10(24)$ & $41(100)$ & 11.331 & 1 & .001 \\
\hline 5. LTINV & $74(70)$ & $31(30)$ & $105(100)$ & 20.240 & 1 & .000 \\
\hline 6. DTA & $25(78)$ & $7(22)$ & $32(100)$ & 10.543 & 1 & .001 \\
\hline 7. INV & $61(80)$ & $15(20)$ & $76(100)$ & 30.733 & 1 & .000 \\
\hline 8. STINV & $83(89)$ & $10(11)$ & $93(100)$ & 64.754 & 1 & .000 \\
\hline 9. $L I A B$ & $53(82)$ & $12(18)$ & $65(100)$ & 28.124 & 1 & .000 \\
\hline 10. CONTIN & $31(78)$ & $9(22)$ & $40(100)$ & 12.730 & 1 & .000 \\
\hline 11. REPER & $32(71)$ & $13(29)$ & $45(100)$ & 8.495 & 1 & .004 \\
\hline 12. ACLOSS & $89(91)$ & $9(9)$ & $98(100)$ & 74.320 & 1 & .000 \\
\hline 13. INFOM & $14(29)$ & $35(71)$ & $49(100)$ & 9.581 & 1 & .002 \\
\hline 14. $N E G W C$ & $38(81)$ & $9(19)$ & $47(100)$ & 18.999 & 1 & .000 \\
\hline 15. SUBSEQ & $13(93)$ & $1(7)$ & $14(100)$ & 10.467 & 1 & .001 \\
\hline \multicolumn{7}{|c|}{ C. Other circumstances disclosed (GRALCOM) } \\
\hline 16. REGUL & $14(82)$ & $3(18)$ & $17(100)$ & 7.271 & 1 & .007 \\
\hline 17. ENVIR & $51(81)$ & $12(19)$ & $63(100)$ & 26.184 & 1 & . 000 \\
\hline 18. $M G M T P$ & $48(87)$ & $7(13)$ & $55(100)$ & 32.796 & 1 & .000 \\
\hline 19. $G C$ & $183(93)$ & $14(7)$ & $197(100)$ & 191.724 & 1 & .000 \\
\hline 20. INPROC & $92(98)$ & $2(2)$ & $94(100)$ & 97.515 & 1 & .000 \\
\hline
\end{tabular}

This table reports the frequency of audit report disclosures in the distressed, non-distressed and overall sample. Absolute figures of the second, third and fourth column represent disclosures of every class that appear in each sample, and percentages of the overall sample are reported in parenthesis. The last three columns show the Chi-Square statistic, degrees of freedom (Df) and significance to examine differences in the distribution between distressed and non-distressed firms. Variables are EMPHA: emphasis of matter; $S C O P E$ : scope limitation; GAAPV: GAAP violation; TNINA: non-current assets: tangibles and intangibles; LTINV: non-current assets: long-term financial investments; DTA: non-current assets: deferred tax assets; $I N V$ : current assets: inventories; STINV: current assets: short-term financial investments and cash; LIAB: liabilities: debts; CONTIN: contingencies; REPER: result of the period; ACLOSS: accumulated losses; INFOM: information omitted; $N E G W C$ : negative working capital; SUBSEQ: subsequent events; REGUL: regulatory effects; ENVIR: external economic environment; MGMTP: management plan; GC: going concern; INPROC: insolvency proceedings; $A C C O M$ : sum of accounting disclosures; GRALCOM: sum of general disclosures. 
Table 8. Correlation matrix and multicollinearity diagnostic statistics

\begin{tabular}{|c|c|c|c|c|c|c|c|}
\hline Variable & $W C T A$ & RETA & EBITTA & BVETL & $A U O P I$ & $A C C O M$ & GRALCOM \\
\hline \multicolumn{8}{|c|}{ Panel 1. Correlation matrix } \\
\hline WCTA & 1.000 & & & & & & \\
\hline \multirow[t]{2}{*}{ RETA } & .657 & 1.000 & & & & & \\
\hline & .000 & & & & & & \\
\hline \multirow[t]{2}{*}{ EBITTA } & .524 & .671 & 1.000 & & & & \\
\hline & .000 & .000 & & & & & \\
\hline \multirow[t]{2}{*}{ BVETL } & .326 & 461 & .193 & 1.000 & & & \\
\hline & .000 & .000 & .000 & & & & \\
\hline \multirow[t]{2}{*}{ AUOPI } & -.187 & -.189 & -.154 & -.153 & 1.000 & & \\
\hline & .000 & .000 & .000 & .000 & & & \\
\hline \multirow[t]{2}{*}{$A C C O M$} & -.308 & -.302 & -.216 & -.191 & .578 & 1.000 & \\
\hline & .000 & .000 & .000 & .000 & .000 & & \\
\hline \multirow[t]{2}{*}{ GRALCOM } & -.170 & -.229 & -.196 & -.143 & .020 & .324 & 1.000 \\
\hline & .000 & .000 & .000 & .000 & .569 & .000 & \\
\hline \multicolumn{8}{|c|}{ Panel 2. Multicollinearity diagnostic statistics } \\
\hline VIF & 1.849 & 2.825 & 1.941 & 1.329 & 1.590 & 1.843 & 1.209 \\
\hline TOL & .541 & .354 & .515 & .752 & .629 & .543 & .827 \\
\hline
\end{tabular}

Panel 1 of this table presents the Pearson correlation matrix of all the accounting (WCTA, RETA, EBITTA and BVETL) and auditing ( $A U O P I, A C C O M$ and GRALCOM) variables included in the models, except for audit report disclosures. P-values are reported below each Pearson coefficient and show the probability of observing this correlation under the null hypothesis that the correlation is zero. Also, we have explored the correlations of audit report disclosures and there are no multicollinearity issues among them (untabulated). Panel 2 reports the Tolerance value (TOL) and its reciprocal, the Variance Inflation Factors (VIF), two tests that detect the presence of multicollinearity among the variables. 
Table 9. Logit models of financial distress probability

\begin{tabular}{|c|c|c|c|c|c|}
\hline Variable & Model 1 & Model 2 & Model 3 & Model 4 & Model 5 \\
\hline WCTA & $\begin{array}{c}-2.035 * * * \\
(.392)\end{array}$ & $\begin{array}{c}-1.908^{* * * *} \\
(.403)\end{array}$ & $\begin{array}{c}-1.699 * * * \\
(.420)\end{array}$ & $\begin{array}{c}-1.676^{* * * *} \\
(.432)\end{array}$ & $\begin{array}{c}-1.688^{* * * *} \\
(.474)\end{array}$ \\
\hline RETA & $\begin{array}{r}-.443 \\
(.447)\end{array}$ & $\begin{array}{r}-.373 \\
(.437)\end{array}$ & $\begin{array}{r}-.107 \\
(.449)\end{array}$ & $\begin{array}{c}.122 \\
(.458)\end{array}$ & $\begin{array}{r}-.043 \\
(.496)\end{array}$ \\
\hline EBITTA & $\begin{array}{c}-7.227^{* * * *} \\
(1.165)\end{array}$ & $\begin{array}{c}-6.565^{* * * *} \\
(1.160)\end{array}$ & $\begin{array}{c}-5.997 * * * * \\
(1.194)\end{array}$ & $\begin{array}{c}-6.293 * * * \\
(1.232)\end{array}$ & $\begin{array}{c}-6.033 * * * * \\
(1.286)\end{array}$ \\
\hline BVETL & $\begin{array}{c}-.297^{* *} \\
(.119)\end{array}$ & $\begin{array}{c}-.254 * * \\
(.113)\end{array}$ & $\begin{array}{c}-.254^{* *} \\
(.118)\end{array}$ & $\begin{array}{c}-.332 * * * \\
(.126)\end{array}$ & $\begin{array}{c}-.350^{* * *} \\
(.153)\end{array}$ \\
\hline$A U O P I$ & & $\begin{array}{c}-1.653^{* * * *} \\
(.225)\end{array}$ & & & \\
\hline ACCOM & & & & $\begin{array}{c}1.031 * * * \\
(.151)\end{array}$ & \\
\hline GRALCOM & & & & $\begin{array}{c}1.041 * * * \\
(.190)\end{array}$ & \\
\hline ЕМРНА & & & $\begin{array}{c}-1.547 * * * * \\
(.252)\end{array}$ & & \\
\hline SCOPE & & & $\begin{array}{c}-2.705 * * * * \\
(.339)\end{array}$ & & \\
\hline GAAPV & & & $\begin{array}{c}-1.213 * * * * \\
(.284)\end{array}$ & & \\
\hline TNINA & & & & & $\begin{array}{c}1.403 * * * \\
(.539)\end{array}$ \\
\hline LTINV & & & & & $\begin{array}{c}1.303 * * * \\
(.357)\end{array}$ \\
\hline DTA & & & & & $\begin{array}{c}.471 \\
(.622)\end{array}$ \\
\hline$I N V$ & & & & & $\begin{array}{c}1.598^{* * * *} \\
(.486)\end{array}$ \\
\hline STINV & & & & & $\begin{array}{c}2.582 * * * * \\
(.563)\end{array}$ \\
\hline LIAB & & & & & $\begin{array}{c}.269 \\
(.514)\end{array}$ \\
\hline CONTIN & & & & & $\begin{array}{c}.942 \\
(.595)\end{array}$ \\
\hline REPER & & & & & $\begin{array}{c}1.702 * * * \\
(.562)\end{array}$ \\
\hline ACLOSS & & & & & $\begin{array}{c}.442 \\
(.562)\end{array}$ \\
\hline INFOM & & & & & $\begin{array}{l}-.505 \\
(.538)\end{array}$ \\
\hline$N E G W C$ & & & & & $\begin{array}{l}-.955 \\
(.671)\end{array}$ \\
\hline SUBSEQ & & & & & $\begin{array}{c}1.104 \\
(1.143)\end{array}$ \\
\hline REGUL & & & & & $\begin{array}{c}.958 \\
(1.148)\end{array}$ \\
\hline ENVIR & & & & & $\begin{array}{c}.526 \\
(.611)\end{array}$ \\
\hline MGMTP & & & & & $\begin{array}{c}-.198 \\
(.755)\end{array}$ \\
\hline$G C$ & & & & & $\begin{array}{c}2.376 * * * \\
(.596)\end{array}$ \\
\hline INPROC & & & & & $\begin{array}{c}1.138 \\
(.871)\end{array}$ \\
\hline
\end{tabular}


Table 9 (cont.). Logit models of financial distress probability

\begin{tabular}{lccccc}
\hline \multicolumn{1}{c}{ Variable } & Model 1 & Model 2 & Model 3 & Model 4 & Model 5 \\
\hline Constant & .167 & $1.191^{* * *}$ & $4.293^{* * *}$ & $-1.160^{* * * *}$ & $-1.180^{* * *}$ \\
& $(.123)$ & $(.196)$ & $(.480)$ & $(.192)$ & $(.207)$ \\
Observations & 808 & 808 & 808 & 808 & 808 \\
Year & $\mathrm{t}-1$ & $\mathrm{t}-1$ & $\mathrm{t}-1$ & $\mathrm{t}-1$ & $\mathrm{t}-1$ \\
Model & Logit & Logit & Logit & Logit & Logit \\
\hline
\end{tabular}

This table presents the results of the logit models of financial distress prediction. Models include accounting ratios only (Model 1) or a combination of ratios and auditing information (Models 2-5). All estimations are computed for the year prior to insolvency proceedings (t-1). Standard errors appear in parenthesis. ***, **, * denote statistical significance at the 1 percent, 5 percent, and 10 percent levels, respectively.

Table 10. Performance measures and classification accuracy of the logit models

\begin{tabular}{|c|c|c|c|c|c|c|}
\hline \multicolumn{7}{|c|}{ Panel 1. Performance measures of the logit models } \\
\hline \multicolumn{2}{|l|}{ Measure } & Model 1 & Model 2 & Model 3 & Model 4 & Model 5 \\
\hline \multicolumn{2}{|l|}{ AUC } & .861 & .878 & .906 & .919 & .929 \\
\hline \multicolumn{2}{|c|}{-2 log-likelihood } & 597.030 & 539.148 & 480.869 & 456.548 & 409.456 \\
\hline \multicolumn{2}{|c|}{ Cox \& Snell $R$-square } & .331 & .392 & .448 & .469 & .509 \\
\hline \multicolumn{2}{|c|}{ Nagelkerke $R$-square } & .441 & .523 & .597 & .626 & 679 \\
\hline \multicolumn{2}{|c|}{ Chi-square $(4,5,7,6,21)$} & 243.975 & 301.857 & 360.136 & 384.457 & 431.548 \\
\hline \multicolumn{2}{|c|}{ p-value } & .000 & .000 & .000 & .000 & .000 \\
\hline \multicolumn{7}{|c|}{ HL goodness-of-fit test: } \\
\hline \multicolumn{2}{|c|}{ Chi-square (8) } & 32.815 & 11.257 & 15.601 & 17.111 & 12.008 \\
\hline \multicolumn{2}{|c|}{ p-value } & .000 & .188 & .048 & .029 & .151 \\
\hline \multicolumn{7}{|c|}{ Panel 2. Classification accuracy of the logit models } \\
\hline \multirow{3}{*}{\multicolumn{2}{|c|}{ Classification accuracy }} & Model 1 & Model 2 & Model 3 & Model 4 & Model 5 \\
\hline & & \multicolumn{5}{|c|}{ Observed (estimation sample) } \\
\hline & & Dist. & Dist. Non & Dist. $\quad$ Non & Dist. Non & Dist. \\
\hline \multirow{4}{*}{ Predicted } & Dist. & 216 & 222 & 243 & 238 & 242 \\
\hline & Non & 267 & 266 & 263 & 274 & 279 \\
\hline & Correct, \% & 85.6 & $75.3 \quad 85.3$ & $82.4 \quad 84.3$ & 80.7 & 82.0 \\
\hline & Overall, \% & 79.6 & 80.4 & 83.4 & 84.3 & 85.8 \\
\hline & & \multicolumn{5}{|c|}{ Observed (test sample) } \\
\hline & & Dist. & Dist. & Dist. & Dist. & Dist. \\
\hline \multirow{4}{*}{ Predicted } & Dist. & 71 & 73 & 79 & 89 & 10 \\
\hline & Non & 38 & 36 & 30 & 20 & 82 \\
\hline & Correct, $\%$ & $\begin{array}{ll}65.1 & 92.4\end{array}$ & $\begin{array}{ll}67.0 & 84.8\end{array}$ & $\begin{array}{ll}72.5 & 87.0\end{array}$ & $\begin{array}{ll}81.7 & 93.5\end{array}$ & $\begin{array}{ll}78.9 & 89.1\end{array}$ \\
\hline & Overall, \% & 77.6 & 75.1 & 79.1 & 87.1 & 83.6 \\
\hline
\end{tabular}

In this table, Panel 1 displays the performance measures of the five logit models of financial distress prediction. Model 1 includes accounting ratios only, and Models 2-5 combine ratios and auditing information. AUC (Area Under the Receiver Operating Characteristics Curve) represents a direct measure of the predictive accuracy of models estimated using logistic regressions. The other measures reported are -2 log-likelihood, Cox and Snell R-square, Nagelkerke R-square, models' Chi-square, and Hosmer and Lemeshow (HL) goodness-of-fit test. The parenthesis following the models' Chi-square includes the degrees of freedom for each estimated model: 4 for Model 1, 5 for Model 2, 7 for Model 3, 6 for Model 4 and 21 for Model 5. Panel 2 contains the classification accuracy of the models. It is calculated with the sample used to run the regression (estimation sample, $75 \%$ of the total sample) and the test sample $(25 \%$ remaining) to validate the results. Absolute numbers for distressed (Dist.) and non-distressed (Non) firms are the observed values, and the correct predicted values are displayed in percentage for distress and nondistressed samples, as well as for the overall dataset.

Figure 1. ROC Curves for the estimated models 


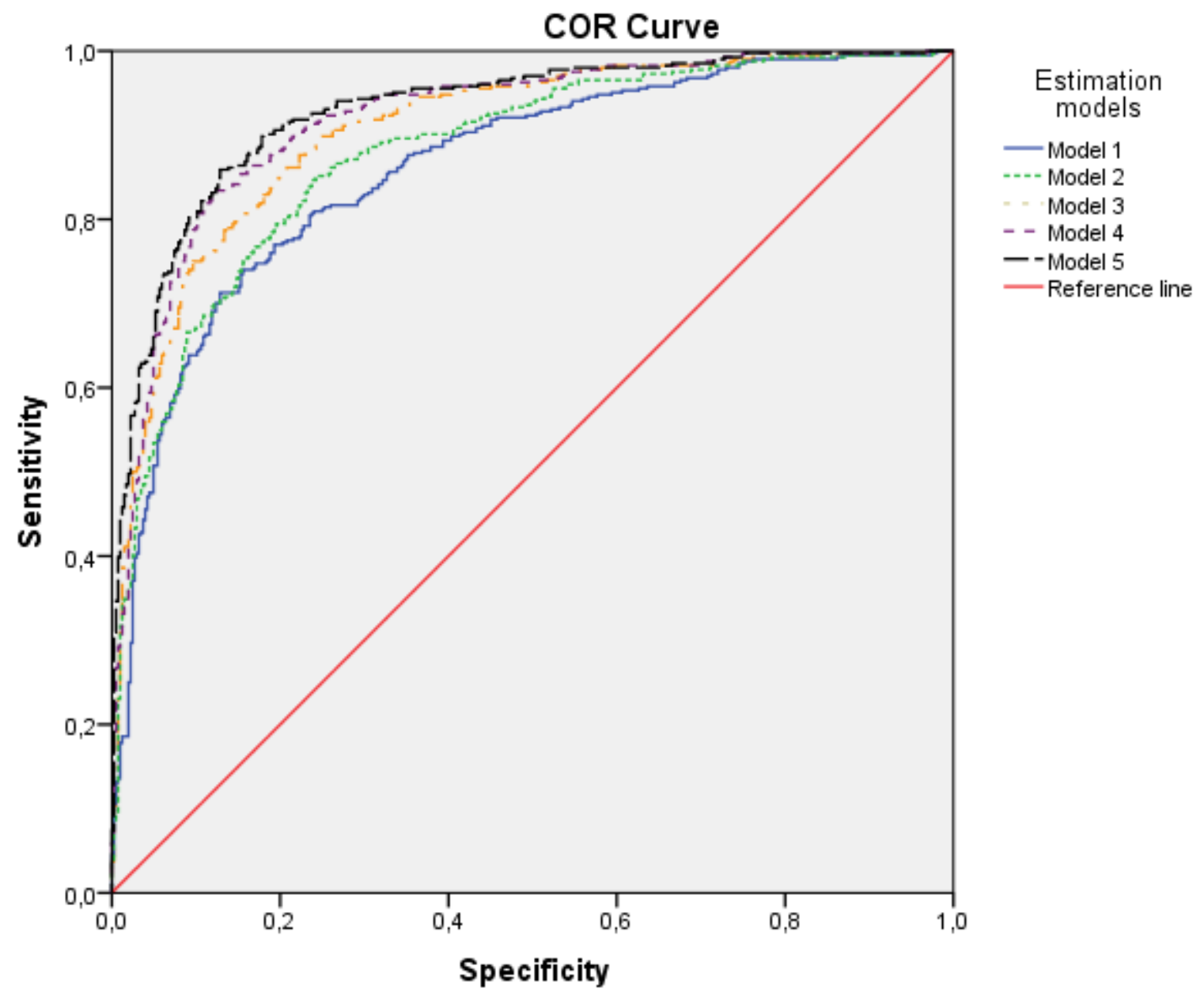

This graph represents the Receiver Operating Characteristics (COR) Curves of the estimated logit models. Model 1 includes accounting ratios only and the different combinations of ratios and auditing information are contained in Models 2 to 5 . 


\section{References}

Acosta-González, E. and F. Fernández-Rodríguez, "Forecasting financial failure of firms via genetic algorithms," Computational Economics, 43 (2014), pp. 133-157.

Altman, E.I., "Financial ratios, discriminant analysis and the prediction of corporate bankruptcy," The Journal of Finance, 23 (1968), pp. 589-609.

Altman, E.I. and T.P McGough, "Evaluation of a Company as a Going-Concern," Journal of Accountancy, 138 (1974), pp. 50-57.

Altman, E.I., "Corporate Financial Distress. A Complete Guide to Predicting, Avoiding, and Dealing with Bankruptcy," (New York: Wiley Interscience, John Wiley and Sons, 1983).

Altman, E.I., "A further empirical investigation of the bankruptcy cost question," The Journal of Finance, 39 (1984), pp. 1067-1089.

Altman, E.I., Iwanicz-Drozdowska, M., E.K. Laitinen and A. Suvas, "Financial and NonFinancial Variables as Long-Horizon Predictors of Bankruptcy," (Working paper SSRN, doi: 10.2139/ssrn.2669668, 2015).

Altman, E.I., Iwanicz-Drozdowska, M., E.K. Laitinen and A. Suvas, "Financial distress prediction in an international context: A review and empirical analysis of Altman's Z-Score model," Journal of International Financial Management and Accounting, 27 (2017), pp. 131-171.

Altman, E.I. and G. Sabato, "Modelling credit risk for SMEs: Evidence from the US market," ${ }^{16}$ Abacus, 43 (2007), pp. 332-357.

Altman, E.I., Sabato, G. and N. Wilson, "The value of non-financial information in small and medium-sized enterprise risk management," Journal of Credit Risk, 2 (2010), pp. 95-127.

American Institute of Certified Public Accountants [AICPA], Statements on Auditing Standards (SAS) No. 59, "The auditor's consideration of an entity's ability to continue as a going concern," (https://www.aicpa.org/, 1988).

Andrade, G. and S.N. Kaplan, "How costly is financial not economic distress? Evidence from highly leveraged transactions that became distressed," The Journal of Finance, 53 (1998), pp. 1443-1493.

Argenti, J., "Corporate collapse: the causes and symptoms," (New York: McGraw-Hill, 1976).

Arnedo-Ajona, L., Lizarraga-Dallo, F. and S. Sánchez-Alegría, "Going-concern uncertainties in pre-bankrupt audit reports: new evidence regarding discretionary accruals and wording ambiguity," International Journal of Auditing, 12 (2008), pp. 25-44.

Back, P., "Explaining financial difficulties based on previous payment behavior, management background variables and financial ratios," European Accounting Review, 14 (2005), pp. 839868.

Balcaen, S. and H. Ooghe, "35 years of studies on business failure: an overview of the classic statistical methodologies and their related problems," The British Accounting Review, 38 (2006), pp. 63-93.

Barker, V.L. and I.M. Duhaime, "Strategic change in the turnaround process: Theory and empirical evidence," Strategic Management Journal, 18 (1997), pp. 13-38.

Bauer, T.D., "The effects of client identity strength and professional identity salience on auditor judgments," The Accounting Review, 90 (2015), pp. 95-114.

Bauweraerts, J., "Predicting bankruptcy in private firms: towards a stepwise regression procedure," International Journal of Financial Research, 7 (2016), pp. 147-153.

Beaver, W.H., "Financial ratios as predictors of failure," Journal of Accounting Research, 4 (1966), pp. 71-111.

Bellovary, J.L., Giacomino, D.E. and M.D. Akers, “A review of bankruptcy prediction studies: 1930 to present," Journal of Financial Education, 33 (2007), pp. 1-42. 
Blay, A.D., "Independence threats, litigation risk, and the auditor's decision process," Contemporary Accounting Research, 22 (2005), pp. 759-789.

Blay, A.D., Geiger, M.A. and D.S. North, "The auditor's going-concern opinion as a communication of risk," Auditing: A Journal of Practice and Theory, 30 (2011), pp. 77-102.

Del Brío-González, E.B., "Efecto de las salvedades de los informes de auditoría sobre el precio de las acciones en la bolsa de Madrid," Spanish Journal of Finance and Accounting, 27 (1998), pp. 129-170.

Camacho-Miñano, M.M., Segovia-Vargas, M.J. and D. Pascual-Ezama, "Which characteristics predict the survival of insolvent firms? An SME reorganization prediction model," Journal of Small Business Management, 53 (2015), pp. 340-354.

Carcello, J.V. and T.L. Neal, "Audit committee characteristics and auditor dismissals following "new" going-concern reports," The Accounting Review, 78 (2003), pp. 95-117.

Carey, P.J., Geiger, M.A. and B.T. O'Connell, "Costs associated with going-concern-modified audit opinions: an analysis of the Australian audit market," Abacus, 44 (2008), pp. 61-81.

Carson, E., Fargher, N.L., M.A. Geiger, C.S. Lennox, K. Raghunandan and M. Willekens, "Audit reporting for going-concern uncertainty: a research synthesis," Auditing: A Journal of Practice and Theory, 32 (2013), pp. 353-384.

Charitou, A., Lambertides, N. and L. Trigeorgis, "Earnings behavior of financially distressed firms: the role of institutional ownership," Abacus, 43 (2007), pp. 271-296.

Cheng, J.H., Yeh, C.H. and Y.W. Chiu, "Improving business failure predication using rough sets with non-financial variables," International Conference on Adaptive and Natural Computing Algorithms in Warsaw, Springer-Heidelberg (2007), pp. 614-621.

Cultrera, L. and X. Brédart, "Bankruptcy prediction: the case of Belgian SMEs," Review of Accounting and Finance, 15 (2016), pp. 1-23.

DeLong, E.R., DeLong, D.M. and D.L. Clarke-Pearson, "Comparing the areas under two or more correlated receiver operating characteristic curves: a nonparametric approach," Biometrics, 44 (1988), pp. 837-845.

Du Jardin, P., "Bankruptcy prediction using terminal failure processes," European Journal of Operational Research, 242 (2015), pp. 286-303.

Du Jardin, P., "Dynamics of firm financial evolution and bankruptcy prediction," Expert Systems with Applications, 75 (2017), pp. 25-43.

Firth, M., "Qualified audit reports: their impact on investment decisions," The Accounting Review, 53 (1978), pp. 642-650.

Flagg, J.C., Giroux, G.A. and C.E. Wiggins, "Predicting corporate bankruptcy using failing firms," Review of Financial Economics, 1 (1991), pp. 67-78.

Geiger, M.A., Raghunandan, K. and D.V. Rama, "Costs associated with going-concern modified audit opinions: an analysis of auditor changes, subsequent opinions, and client failures," Advances in Accounting, 16 (1998), pp. 117-139.

Grunert, J., Norden, L. and M. Weber, "The role of non-financial factors in internal credit ratings," Journal of Banking and Finance, 29 (2005), pp. 509-531.

Herbohn, K. and V. Ragunathan, "Auditor reporting and earnings management: some additional evidence," Accounting and Finance, 48 (2008), pp. 575-601.

Hernández-Tinoco, M. and N. Wilson, "Financial distress and bankruptcy prediction among listed companies using accounting, market and macroeconomic variables," International Review of Financial Analysis, 30 (2013), pp. 394-419.

Hillegeist, S.A., Keating, E.K., D.P. Cram and K.G. Lundstedt, "Assessing the probability of bankruptcy," Review of Accounting Studies, 9 (2004), pp. 5-34. 
Hopwood, W., McKeown, J. and J. Mutchler, "A test of the incremental explanatory power of opinions qualified for consistency and uncertainty," The Accounting Review, 64 (1989), pp. 2848.

International Auditing and Assurance Standards Board [IAASB], International Standard on Auditing (ISA) No. 570, 2015, Going concern [https://www.ifac.org/].

Keasey, K. and R. Watson, "Non-financial symptoms and the prediction of small company failure: a test of Argenti's hypotheses," Journal of Business Finance and Accounting, 14 (1987), pp. 335354.

Kim, M., Kim, M. and McNiel, R.D. (2008). "Predicting survival prospect of corporate restructuring in Korea," Applied Economics Letters, 15 (2008), pp. 1187-1190.

Knechel, W.R. and A. Vanstraelen, "The relationship between auditor tenure and audit quality implied by going concern opinions," Auditing: A Journal of Practice and Theory, 26 (2007), pp. 113-131.

Kumar, P.R. and V. Ravi, "Bankruptcy prediction in banks and firms via statistical and intelligent techniques: a review," European Journal of Operational Research, 180 (2007), pp. 1-28.

Kuruppu, N., F. Laswad and P. Oyelere, "The efficacy of liquidation and bankruptcy prediction models for assessing going concern," Managerial Auditing Journal, 18(2003), pp. 577-590.

Laitinen, E.K., "Financial ratios and different failure processes," Journal of Business Finance and Accounting, 18 (1991), pp. 649-674.

Laitinen, E.K., "Predicting a corporate credit analyst's risk estimate by logistic and linear models," International Review of Financial Analysis, 8 (1999), pp. 97-121.

Laitinen, E.K., "Do reorganizing and bankrupt firms differ from viable firms?" Proceedings of the IASK International Conference, Global Management, 2009, pp. 185-194.

Laitinen, E.K. and T. Laitinen, "Misclassification in bankruptcy prediction in Finland: human information processing approach," Accounting, Auditing and Accountability Journal, 11 (1998), pp. 216-244.

Laitinen, E.K. and T. Laitinen, "Effect of accruals on financial, non-financial, and audit information in payment default prediction," International Journal of Accounting, Auditing and Performance Evaluation, 5 (2009a), pp. 353-383.

Laitinen, E.K., and T. Laitinen, "Audit report in payment default prediction: a contingency approach," International Journal of Auditing, 13 (2009b), pp. 259-280.

Lennox, C.S., "The accuracy and incremental information content of audit reports in predicting bankruptcy," Journal of Business Finance and Accounting, 26 (1999), pp. 757-778.

Liu, J., "Macroeconomic determinants of corporate failures: evidence from the UK," Applied Economics, 36 (2004), pp. 939-945.

Lizarraga-Dallo, F., "Modelos de previsión del fracaso empresarial: ¿funciona entre nuestras empresas el modelo de Altman de 1968?," Spanish Accounting Journal, 1 (1998), pp. 137-164.

Lukason, O. and R.C. Hoffman, "Firm bankruptcy probability and causes: An integrated study," International Journal of Business and Management, 9 (2014), pp. 80-91.

Luoma, M. and E.K. Laitinen, "Survival analysis as a tool for company failure prediction," Omega, 19 (1991), pp. 673-678.

Lussier, R.N., "A nonfinancial business success versus failure prediction model for young firms," Journal of Small Business Management, 33 (1995), pp. 8-20.

Maltz, A.C., Shenhar, A.J. and R.R. Reilly, "Beyond the balanced scorecard: refining the search for organizational success measures," Long Range Planning, 36 (2003), pp. 187-204.

McKee, T.E., "Rough sets bankruptcy prediction models versus auditor signaling rates," Journal of Forecasting, 22 (2003), pp. 569-586. 
Merton, R.C., "On the pricing of corporate debt: the risk structure of interest rates," The Journal of Finance, 29 (1974), pp. 449-470.

Muñoz-Izquierdo, N. Camacho-Miñano, M.M. and D. Pascual-Ezama, "The content of the audit report in the year prior to bankruptcy filing. Empirical evidence from Spain," Spanish Journal of Finance and Accounting, 46 (2017), pp. 92-126.

Mutchler, J., "Auditors' perceptions of the going concern opinion decision," Auditing: A Journal of Practice and Theory, 3 (1984), pp. 17-30.

Mutchler, J., "A multivariate analysis of the auditor's going concern opinion decision," Journal of Accounting Research, 23 (1985), pp. 668-682.

Neter, J., Wasserman, W. and M.H. Kutner, "Applied linear regression models," (Ann Arbor: University of Michigan, 1989).

Ohlson, J.A., "Financial ratios and the probabilistic prediction of bankruptcy," Journal of Accounting Research, 18 (1980), pp. 109-131.

Peel, M.J. and D.A. Peel, "Some further empirical evidence on predicting private company failure," Accounting and Business Research, 18 (1987), pp. 57-66.

Peel, M.J., Peel, D.A. and P.F. Pope, "Predicting corporate failure-some results for the UK corporate sector," Omega, 14 (1986), pp. 5-12.

Piñeiro-Sánchez, C., De Llano-Monelos, P. and M. Rodríguez-López, “A parsimonious model to forecast financial distress, based on audit evidence," Contaduría y Administración, 58 (2013), pp. $151-173$.

Pozuelo-Campillo, J., Labatut-Serer, G. and E.J. Veres-Ferrer, "Análisis descriptivo de los procesos de fracaso empresarial en microempresas mediante técnicas multivariantes," Revista Europea de Dirección y Economía de la Empresa, 19 (2010), pp. 47-66.

Reznakova, M. and M. Karas, "Bankruptcy prediction models: can the prediction power of the models be improved by using dynamic indicators?" Procedia Economics and Finance, 12 (2014), pp. 565-574.

Ruiz-Barbadillo, E., Gómez-Aguilar, N. and G. Aguilar-Contreras, "Una comparación intersectorial y por tamaño de la calidad de la información contable a través del análisis del informe de auditoría," Spanish Journal of Finance and Accounting, 31 (2002), pp. 545-581.

Ruiz-Barbadillo, E., Gómez-Aguilar, N., C. De Fuentes-Barberá and M.A. García-Benau, "Audit quality and the going-concern decision-making process: Spanish evidence," European Accounting Review, 13 (2004), pp. 597-620.

Sánchez-Segura, A., "Factores determinantes del retraso en la emisión del informe de auditoría. Un análisis empírico," Spanish Accounting Review, 3 (2000), pp. 145-175.

Schwartz, K.B. and K. Menon, "Auditor switches by failing firms," The Accounting Review, 60 (1985), pp. 248-261.

Scott, J., "The probability of bankruptcy," Journal of Banking and Finance, 5 (1981), pp. 317344.

Sun L., "A re-evaluation of auditors' opinions versus statistical models in bankruptcy prediction," Review of Quantitative Finance and Accounting, 28 (2007), pp. 55-78.

Sun, J., Li, H., Q.H. Huang and K.Y. He, "Predicting financial distress and corporate failure: a review from the state-of-the-art definitions, modeling, sampling, and featuring approaches," Knowledge-Based Systems, 57 (2014), pp. 41-56.

Tascón-Fernández, M.T. and F.J. Castaño-Gutiérrez, "Variables y modelos para la identificación y predicción del fracaso empresarial: revisión de la investigación empírica reciente," Spanish Accounting Review, 15 (2012), pp. 7-58. 
Whitaker, R.B., "The early stages of financial distress," Journal of Economics and Finance, 23 (1999), pp. 123-132.

Wilson, N., Wright, M. and L. Scholes, "Family business survival and the role of boards," Entrepreneurship Theory and Practice, 37 (2013), pp. 1369-1389.

Wruck, K.H., "Financial distress, reorganization, and organizational efficiency," Journal of Financial Economics, 27 (1990), pp. 419-444.

$\mathrm{Wu}$, Y., Gaunt, C. and S. Gray, "A comparison of alternative bankruptcy prediction models," Journal of Contemporary Accounting and Economics, 6 (2010), pp. 34-45.

Zmijewski, M.E., "Methodological issues related to the estimation of financial distress prediction models," Journal of Accounting research, 22 (1984), pp. 59-82. 


\section{Endnotes:}

${ }^{1}$ Beaver (1966) applies a univariate technique for selected ratios and Altman (1968) develops a multiple discriminant analysis model (MDA) called the Z-Score model.

${ }^{2}$ The Bureau Van Dijk database in Spain is called SABI ("Sistema de Análisis de Balances Ibéricos").

${ }^{3}$ The "Registro Público Concursal" is the official source about insolvency legal proceedings in Spain.

${ }^{4}$ In Spain, the law governing this procedure is the Bankruptcy Act 22/2003 of July $9^{\text {th }}$, which comes into effect in 2004. According to this regulation, when a company is under financial distress, managers or creditors present an insolvency request to the judge and a single court procedure starts. All viable firms should finish proceedings by being reorganized, and those inviable should end with their liquidation (Camacho-Miñano et al., 2015).

${ }^{5}$ GAAP means Generally Accepted Accounting Principles.

${ }^{6}$ Along the paper the term disclosures in the audit report is used to refer to both qualifications and unqualified audit opinions that contain an emphasis of matter section.

${ }^{7}$ SSAP means "Statements of Standard Accounting Practice".

${ }^{8}$ In BVD database the search was done as of January $31^{\text {st }}, 2015$ by status, using the following three: "suspension of payment proceedings", "bankruptcy", and "insolvency proceedings". Also, in order to include audited companies only, results were filtered by companies with information under the field "auditor's opinion". The result was the initial sample of the study. Later, it is manually verified that firms were registered in the RPC (excluding the ones that were not) and had enough financial and audit data of the year prior to the insolvency situation.

9 The NACE codification is the Statistical Classification of economic activities in the European Community, abbreviated as NACE.

${ }^{10}$ There were more insolvency legal proceedings in Spain ongoing during the years covered in the sample. However, due to the database configuration, it is not possible to determine which companies were under proceedings in the past if their processes are not ongoing as of the date of the data extraction. Thus, a limitation of our sample is that it includes only the proceedings that were ongoing as of January $31^{\text {st }}, 2015$. ${ }^{11}$ In the BVD database for Spanish firms, the balance sheet and income statement lines extracted to calculate the ratios are as follows: $W C T A=[$ (Stocks + debtors + other current assets + cash \& cash equivalents) - (loans + creditors + other current liabilities) $] /$ total assets; $R E T A=$ (Shareholders' funds capital) / total assets; EBITTA = Operating P/L / total assets; BVETL = Shareholders' funds / (non-current liabilities + current liabilities).

${ }^{12}$ Similarly, for the purposes of this paper, any audit opinion in the dataset with an emphasis of matter section is considered to be unqualified.

${ }^{13}$ In our paper and in the study of Altman and McGough (1974), the auditor's going concern assessment is almost identical, which may indicate that the behavior of auditors could be generalized to different periods and regulations. Whereas accounting standards applicable to our sample are the Spanish GAAP, the firms used by Altman and McGough (1974) follow US GAAP. There are some differences between the Spanish GAAP, inspired by the IFRS, and the US GAAP. A key difference between both set of standards is that Spanish GAAP indicate principles that firms should follow according to their judgment while US GAAP set rules to prevent opportunistic measures to maximize profits. There are many other examples of relevant differences. For instance, differences related to asset valuation, revenue recognition, and research and development costs, among others. Whereas Spanish GAAP allow for asset revaluation upwards, assets in US GAAP can only be written down. Additionally, in Spanish GAAP, LIFO is not permitted to value inventories but it is allowed under US GAAP. In comparison with no clear specifications about how to recognise revenues under Spanish GAAP, US GAAP provide specific guidance to disclose revenues. Also, while research and development costs might be recorded as assets under Spanish GAAP, these costs are charged to expenses in the American regulation.

${ }^{14}$ This paper also calculates the correlation matrix and the multicollinearity tests for all the independent variables (including the 20-item codification of audit report disclosures that is not presented in the paper). VIF values are below 10, which suggests that multicollinearity is not present and coefficient levels are stable. There is an exception with the VIF for the audit opinion variable (AUOPI), which equals 11.012. This result seems reasonable, as the variables that represent the content of the report are summarized in the audit opinion issued. Therefore, in the multivariate analysis, the audit opinion is not combined with other auditing variables in the same logit model, as the opinion seems to be a linear or quasi-linear combination of the other auditing variables.

${ }^{15}$ As a robustness check, we have also run the five logit regression models using the accounting ratios of the Zmijewski's-Score model Zmijewski, 1984), commonly used in prior literature as well (Sun, 2007; Wu, 
Gaunt and Gray, 2010). The untabulated results are consistent in all models with the evidence obtained using the Altman's Z' -Score. 